San Jose State University

SJSU ScholarWorks

Master's Projects

Master's Theses and Graduate Research

Spring 5-1-2021

\title{
The Impact of Integrating an SBDC Program into a College/ University Career Center
}

Harshdeep Singh Nanda

San Jose State University

Follow this and additional works at: https://scholarworks.sjsu.edu/etd_projects

Part of the Entrepreneurial and Small Business Operations Commons, and the Growth and Development Commons

\section{Recommended Citation}

Nanda, Harshdeep Singh, "The Impact of Integrating an SBDC Program into a College/University Career Center" (2021). Master's Projects. 986.

DOI: https://doi.org/10.31979/etd.ej6m-rtda

https://scholarworks.sjsu.edu/etd_projects/986

This Master's Project is brought to you for free and open access by the Master's Theses and Graduate Research at SJSU ScholarWorks. It has been accepted for inclusion in Master's Projects by an authorized administrator of SJSU ScholarWorks. For more information, please contact scholarworks@sjsu.edu. 
THE IMPACT OF INTEGRATING AN SBDC PROGRAM INTO A COLLEGE/UNIVERSITY CAREER CENTER

\author{
by \\ Harshdeep Singh Nanda

\begin{abstract}
A Thesis Quality Research Project
\end{abstract} \\ Submitted in Partial Fulfillment of the \\ Requirements for the \\ Master's Degree \\ in \\ PUBLIC ADMINISTRATION \\ Prof. Frances L. Edwards, Ph.D.
}

The Graduate School

San Jose State University

May 2021 


\section{BACKGROUND}

\section{Introduction}

With a new approach for integrating the Small Business Development Center (SBDC) program in Alameda County, the Ohlone Community College District (Ohlone College) has introduced a new model for hosting an SBDC program on a college/university campus. While many other educational institutions across the nation have hosted an SBDC program (Cook Center for Entrepreneurship - Ivy Tech Community College of Indiana, n.d.; University of Scranton Small Business Development Center (SBDC) | Helping NEPA \& Northern Tier Small Businesses Start, Grow \& Prosper., n.d.; Olson, 2006), most have treated the program as a separate entity or department, often leading to the program existing as a silo on the campus. Ohlone College, however, has instead taken the program and has fully integrated the program and all of its services into an existing career services center. The Ohlone College Tri-Cities Career Center now serves as the host of the county-wide SBDC program.

This approach for hosting an SBDC program in a college/university career services center is fairly new and innovative. Ohlone College officially became the host of the Alameda County Small Business Development Center (SBDC) in January of 2019 (Our Host: Ohlone College | Alameda SBDC, n.d.). With only two years since the start of this integration, it is difficult to discern yet whether this "new model" for running an SBDC program has been successful, or even viable. However, it is possible to apply a methodology to analyze the impact that this integration has had on the productivity (and thus, success) of the SBDC program, using models of evaluation that have been used for this purpose in the 
past. With a comprehensive quantitative analysis of the productivity of the program, it would then be possible to determine whether this integration is indeed a "successful" one.

Thus, this research paper focuses on addressing the following core research question: "How can the integration of a Small Business Development Center (SBDC) program into a college or university career services center have an impact on the productivity of the SBDC program?"

Before delving into this question, a strong understanding of the background of the various elements involved in this topic - the institutions, programs and history - is required. Once this understanding is developed, the detailed methodology of this research is described, followed by a discussion and an analysis of the findings of this research.

\section{A. The Small Business Administration (SBA) and the Small Business Development Center (SBDC) Program}

In order to analyze the impact of the integration of the Alameda County SBDC program into the Ohlone College Tri-Cities Career Center on the program's productivity, it is vital to understand the roots of the SBA and the SBDC program.

The Small Business Development Center's history dates back to as early as the 1940's, when legislation was introduced in Congress to develop “University-based business extension services" (A Brief History of America's SBDC Network, n.d.). This was then further developed in 1953, when the Small Business Administration (SBA) was established as a "tiny lending agency" that "eventually mushroomed into a multibillion-dollar financial institution" (Bean, 2001; History of SBA, n.d.). In 1977, the SBDC program was introduced as a pilot program in eight states, with the "purpose to fill an unmet need for staff specialists 
and planning consultants in small firms" (Chrisman et al., 1985, 1). This was done under a model of a University Business Development Center, or UBDC (A Brief History of America's SBDC Network, n.d.). The basis of this model was similar to what was being done at the time with land grant colleges, which were supporting agriculture in the surrounding area. Similarly, these UBDC's would support local small businesses in meeting their needs for counseling and advising (Unnamed Press Release | Small Business Administration, 1976).

Why is this so significant? Over time, most SBDCs have transitioned towards being hosted by city offices, non-profits or chambers of commerce and have started to move away from being housed in educational institutions (OBDC Small Business Finance Wins Bid to Host Local SBDC, 2016). However, the purpose of this study is to understand whether there

are benefits to the SBDC program being hosted by a college or university - specifically in the career services department. While there are many other colleges and universities that currently host the SBDC program, such as Ivy Tech Community College of Indiana and the University of Scranton in Pennsylvania, there are no other examples of SBDC programs that have fully integrated within career services departments (Cook Center for Entrepreneurship Ivy Tech Community College of Indiana, n.d.; University of Scranton Small Business Development Center $(S B D C) \mid$ Helping NEPA \& Northern Tier Small Businesses Start, Grow \& Prosper., n.d.; Olson, 2006).

\section{B. The Ohlone Community College District \& The Ohlone Tri-Cities Career Center} The Ohlone Community College District (Ohlone College) is one of 116 community college campuses that fall under the California Community Colleges system - the largest community college system in the nation (Key Facts | California Community Colleges Chancellor's 
Office, n.d.). Ohlone College was established on December $7^{\text {th }}, 1965$, when Fremont and Newark, California voters "approved the creation of the Fremont Newark Junior College District and elected a seven-member Board of Trustees. Ohlone College was established to serve the cities of Fremont and Newark" (History of Ohlone College, 2018). The name Ohlone was introduced to the founders of the institution by a representative of the Ohlone Tribe - highlighting the proud heritage and tradition of the native tribe that once inhabited the region, throughout all of the present-day San Francisco Bay Area (History of Ohlone College, 2018).

Presently, Ohlone College has two campuses (one in Fremont, California and the other in Newark, California) and serves about 15,000 students annually (Quick Facts, 2018). The college offers "189 associate degrees and certificates, including 27 associate degrees for transfer (ADT), 45 associate degrees (AA or AS), 35 certificates of achievement, 67 certificates of accomplishment, and 15 noncredit certificates of completion" (Quick Facts, 2018).

The Ohlone College Tri-Cities Career Center (formerly known as the Tri-Cities OneStop Career Center) was established in 1995, and has since served the Tri-Cities region of Alameda County, California (the cities of Fremont, Newark and Union City) with a variety of services for job seekers, local businesses and other agencies/individuals (Ohlone Career Center, 2018).

The Tri-Cities Career Center is located on Ohlone College's Newark Campus, and is structured to serve four key groups of stakeholders (Career Center, 2018):

1. Students (and alumni) of Ohlone College 
2. Community members - residents of the local community, including students from other institutions

3. Employers - local businesses, non-profits and other agencies that are seeking talent to hire for part-time, full-time, internship or other roles

4. Entrepreneurs - small business owners and aspiring (student \& non-student) entrepreneurs wanting to start a new business. This is a new group of stakeholders that has been recognized with the new integration of the Alameda County SBDC program and its services.

These stakeholders directly drive the development of various tiers of services provided by the center - an intentional decision made by the center staff to organize the center and better serve clients (J. Jimenez, personal communication, October 16, 2020). The menu of services available to students is split into three tiers of service (Career Center, 2018):

1. Self-Directed Services

2. Group Services

3. Individualized Services

The menu of services available to community members is also split into three tiers of service (Career Center, 2018):

1. Self-Directed Services

2. Group Services

3. Individualized Services

The menu of services available to employers (local businesses, non-profit organizations and other agencies seeking talent to hire to fill available job/internship opportunities) is split into five tiers of service (Career Center, 2018): 
1. Self-Directed Services

2. Pre-Recruitment Services

3. Recruitment Services

4. Contract Services

5. Renegade Advocacy ${ }^{1}$

Finally, the newest addition to the career center's menu of services is dedicated to aspiring entrepreneurs (students of the college, or others from the local community) and small business owners across Alameda County. This is split into two sections - Business Owners and Aspiring Entrepreneurs (Career Center, 2018).

(Existing) Business Owners - 3 Tiers:

1. Self-Directed Services

2. Alameda County SBDC Consultations

3. Professional \& Business Development

Aspiring Entrepreneurs - 2 Tiers:

1. Self-Directed Services

2. One-on-One Services

This basic structure for the center provides a general understanding of how the center is organized. However, it also serves another key purpose. At any given point in time over the past two years, the Ohlone College Tri-Cities Career Center has sustained its operations by being funded by between 10 and 14 different funding sources (J. Jimenez, personal communication, October 16, 2020). This tiered structure of services serves as a clear example

${ }^{1}$ The Renegade Advocacy tier refers to a sponsorship program for the career center. "Renegade" is the name of Ohlone College's mascot (Career Center, 2018). 
of the how the center has integrated and met the requirements set forth by the scopes of work for the ranging number of different funding streams - including the funding for the Alameda County Small Business Development Center (SBDC) program contract.

\section{Integration of Other Funding Sources and Contracts into the Ohlone College Tri- Cities Career Center}

The integration of a federal subcontract is not new for the Ohlone College Tri-Cities Career Center. As mentioned earlier, the center has been funded by between 10 and 14 different funding streams at any given point in time. Some of these funding streams include (J.

Jimenez, personal communication, October 16, 2020):

- $\quad$ The Strong Workforce program (Strong Workforce Program | California Community Colleges Chancellor's Office, n.d.)

- $\quad$ The Federal Job Location and Development (JLD) program, under the Federal Work Study (FWS) program (Federal Student Aid - IFAP: Federal Work-Study Program - Job Location and Development, n.d.)

- The Biotech \& Advanced Manufacturing Rapid Reemployment (BAMRR) Grant under the Alameda County Workforce Development Board (ACWDB) (Alameda County Workforce Development Board, 2019)

However, one of the largest funding streams for the career center comes from the Workforce Innovation and Opportunity Act (WIOA) program (J. Jimenez, personal communication, October 16, 2020). The Alameda County Workforce Development Board (ACWDB), “a 27 member employer-led oversight body" oversees the WIOA program for Alameda County ( Workforce Development Board | Alameda County, n.d.). There are four service locations 
available to job seekers in the county to receive WIOA services, one of which is the Ohlone College Tri-Cities Career Center. How has the center integrated the WIOA program and its services into the centers' existing services?

According to Newell (2018), while Ohlone College's Career Center has been a recipient of WIOA funding for many years, it has only recently better integrated the program (and thus the center as a whole) into the college. Newell's research indicated that by better integrating the WIOA program (a federal subcontract) into the institution, the program as a whole was more successful. This not only sets a model for integrating the Alameda County SBDC program (another federal subcontract) but also serves as an indication of the positive impact this integration may have on the performance of the SBDC program overall.

How was the WIOA program better integrated into the institution? According to Newell (2018), the center was not targeting students on campus, when it came to WIOA enrollments. Over a series of months of intervention, the center was able to enroll more students into the program, not only improving the performance of the program, but also providing students with better access to career services and resources - adding to the value of the center at the institution (J. Jimenez, personal communication, October 16, 2020; Newell, 2018).

What did these interventions look like? The center transitioned to a "student-first approach" (J. Jimenez, personal communication, October 16, 2020). These interventions included (Newell, 2018):

- hosting periodic student orientations

- $\quad$ student drop-in counseling appoints twice a week

- $\quad$ student-friendly jobs fairs 
- employer information sessions and panel discussions

- student-focused recruiting events targeting part-time and seasonal employment

- fieldtrips to employer campuses to learn about job and internship opportunities

- student-friendly career development workshops

- social media marketing on LinkedIn, Facebook, and Twitter

- deploying a new Career Services Management (CSM) system

- classroom presentations

- faculty presentations

- administrator collaborations

- reaching across departments and divisions to engage staff

- $\quad$ student email marketing

- employer field trips

- deploying a mentoring program

- integrating with the Financial Aid department to coordinate the Job Location Development (JLD) program through Work-Study, a funding source and program available to all institutions that receive federal work-study funding These interventions were deployed over a series of two program years and then analyzed to determine their effect on increasing student engagement and improving performance of meeting WIOA goals (Newell, 2018).

Apart from these interventions, some organizational changes were also made. The center staff implemented the use of Program Logic Models (PLMs), which were used to record student engagement, and thus assisted with analyzing the effects of the interventions (Newell, 2018). 
The center also deployed a structured "menu of services," as described earlier. This tiered approach gave the center a better way to organize its services and serve clients according to their needs (Career Center, 2018; J. Jimenez, personal communication, October $16,2020)$.

This integration process led to a successful result, as performance of the center in reaching its WIOA goals improved and overall student engagement also improved (Newell, 2018). Thus, this lays a framework for the integration of other federal subcontracts, such as the Alameda County SBDC program. 


\section{LITERATURE REVIEW}

Research on Small Business Development Center (SBDC) programs across the nation reveals that there are many two-year and four-year institutions that serve as hosts of the program in their region. Most of these SBDCs serve as independent departments or programs on campus that are a "resource" for local small businesses (SFCC Employer Services, n.d.). The Alameda County SBDC, however, is unique as it is hosted specifically in the Career Center of the Ohlone Community College District in Newark, California (Our Host: Ohlone College | Alameda SBDC, n.d.). What sets this center apart is that the SBDC program's services are fully integrated into the college and specifically the career center, serving local small businesses throughout the county and serving students on campus by promoting collegiate entrepreneurship (Entrepreneurship Services - Ohlone College Tri-Cities Career Center, 2019).

In order to fully comprehend and analyze the impact of this arrangement, a review of existing literature is required. Although there are no other examples of such an integration to be found, there are similar studies that have been done in the past that can serve as a reference for this study. One of the most notable works, by Newell (2018), examines the same Career Center at Ohlone College and its process for implementing and leveraging another federal subcontract, the Workforce Innovation and Opportunity Act (WIOA) through the Alameda County Workforce Development Board (ACWDB) (Newell, 2018). This work provides a valuable reference for information on the history of the Ohlone Career Center and methodology used to evaluate the center's programs. A few related themes explored by other studies include the history of the SBDC, methods used to evaluate the program, and the importance and impact of entrepreneurship programs in the education system. A full 
understanding of these themes from past work will be beneficial in developing this study (Hart, 2018).

\section{Evaluating an SBDC Program: The Ever-Changing Approach in Methodology}

Previous research on the topic of SBDC evaluation dates back to as early as the inception of the program as a pilot in 1977. The U.S. Small Business Administration (SBA) often had individuals and organizations prepare reports under contract, to evaluate the program (U.S. Small Business Administration, 1979; "Major Impact Study of SBA Management Counseling and Training Programs," 1980; Weaver, 1981; Centaur Associates, Inc., 1983). However, the work done by researchers such as Chrisman et al. (1985), Elstrott (1987), Lang \& Golden (1989) and Thompson et al. (1996) paves the way for specific methodology to be used, when evaluating the effectiveness and eventually the efficiency of SBDC programs (Figure 1).

FIGURE 1: Evaluating an SBDC Program: The Ever-Changing Approach

\section{Evaluating an SBDC Program: The Ever-Changing Approach}

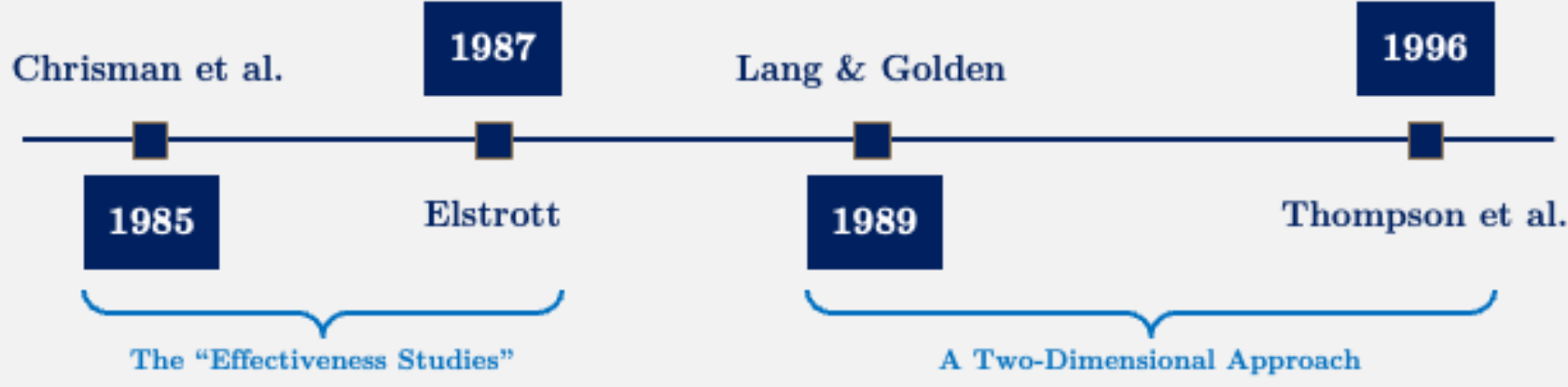




\section{i. Chrisman et al. (1985) \& Elstrott (1987): “The Effectiveness Studies”}

In July of 1985, one of the most notable works on evaluating the productivity and efficiency of the SBDC program was published by a team of two Ph.D. students and two associate professors, all involved with their local SBDC in varying capacities (Chrisman et al., 1985). As mentioned earlier, the SBDC program was initiated on a pilot basis. By the time this work was published, the SBDC program had proven to be a beneficial asset to small business owners and had been assured for continuation by The Small Business Development Center Act of 1979 (Krentzman \& Samaras, 1960; S.918 - 96th Congress (1979-1980), 1980). Up until this point, "independent researchers' conclusions had ${ }_{[s i c]}$ been generally positive, leading to continued federal support for SBDC programs" (U.S. Small Business Administration, 1979; Chrisman et al., 1985; Hodes, 1981; "Major Impact Study of SBA Management Counseling and Training Programs," 1980; Weaver, 1981; Centaur Associates, Inc., 1983).

What sets this research apart from past studies is the methodology used. For this study, Chrisman et al. (1985) used "statewide average changes in sales, employment, capital and profits" (p. 4) for small businesses in Georgia and South Carolina. Through their analysis, they came to the conclusion that the SBDC consulting services in Georgia and South Carolina were cost effective (Chrisman et al., 1987). However, not all researchers were pleased with the way Chrisman et al. (1985) did their study. Elstrott (1987) replicated the study done by Chrisman et al. in 1985 with the state of Louisiana. According to Elstrott, in the process of replicating the research, "problems were encountered which stimulated ideas regarding possible improvements on the quantitative and qualitative evaluation of SBDC consulting 
activities" (Elstrott, 1987, 67). These issues in methodology were acknowledged by Chrisman et al. (1987) when they wrote a response to Elstrott (1987). "Our study did, in fact, make such a trade off when choosing statewide averages to represent the control group. Limitations of resources and time constrained our ability to obtain a control group similar to the one used by Robinson" (Chrisman et al., 1987, 73; Robinson Jr., 1980).

How can the issues faced by Chrisman et al. (1985) and outlined by Elstrott (1987) be addressed in this study? Chrisman et al. (1985) needed to use telephone and mail to conduct their surveys and to collect data from various SBDCs across the states they were studying. Fortunately, the access to modern technology helps alleviate some of the challenges faced by previous researchers; today, access to surveying tools, databases, websites and social media significantly improve the process of developing a sound methodology for research. The Alameda County SBDC, the Northern California SBDC Lead Center and the other SBDCs in the Northern California region all have access to websites, social media and an interconnected customer relationship management (CRM) system and database called Neoserra (Who We Are | Alameda SBDC, n.d.; Who We Are | Northern California SBDC Network, n.d.). Once a methodology is established, gaining access to valid past and present data for SBDCs in the region would not be difficult with access to Neoserra. With access to this data, the study will be more localized by county as opposed to statewide figures and would not risk being unstable, as cautioned by Elstrott (Elstrott, 1987). 


\section{ii. Lang \& Golden (1989) and Thompson et al. (1996): A Two-Dimensional Approach}

In April of 1989, Lang and Golden attempted a new approach to evaluating the SBDC program. While giving credit to the work of Chrisman et al. (1985) and Elstrott (1987), Lang and Golden (1989) highlighted that "earlier approaches to SBDC evaluation have focused on effectiveness measures (e.g. client satisfaction and economic impact) of SBDC performance" (Lang \& Golden, 1989, 42). These approaches were one-dimensional, as they only took into account the performance of the center among its constituents in its locality. Lang and Golden (1989), however, approached their research in a new manner by implementing a new measure for their study - the efficiency of resource utilization by the centers. While any center may boast high performance on an individual level, Lang and Golden (1989) found it vital to compare performance of each center among others. In order to conduct this study, Lang and Golden (1989) used an approach called "Data Envelopment Analysis" (DEA). There are many benefits of the DEA approach. For example, DEA considers "multiple inputs and outputs" and compares efficiency among units with similar resource mixes, to ensure the fairest possible comparison within the state (or other region being studied) (Lang \& Golden, 1989, 43).

The benefits of the DEA method are highlighted again in August of 1996 by the work of Thompson et al. (1996), who also introduced the Assurance Region (AR) method, when evaluating the University of Houston (UH) Small Business Development Centers (Thompson et al., 1996).

Why is this new approach relevant to this study? While conducting a DEA is too complex given the resources available for this study, and it may not even help to 
achieve answering the exact question addressed in this study, it highlights a pathway towards a more comprehensive methodology. Although the work of Chrisman et al. (1985) and Elstrott (1987) gave way to a few factors to be considered when evaluating an SBDC program, the work of Lang \& Golden (1989) and Thompson et al. (1996) emphasizes the need for comparison among other centers. Thus, when analyzing the productivity of the Alameda County SBDC program (and the change thereof, due to the integration of the program into Ohlone College's Career Center), it will also be imperative to compare the productivity of the program among other centers' programs in the Northern California SBDC Network, with "similar resource mixes" (Lang \& Golden, 1989, 43). 


\section{METHODOLOGY}

For this research, a program evaluation of the Alameda County SBDC was conducted, as outlined by Sylvia \& Sylvia (2012). Initially, the program was not performing well, as it often ranked very low among the other SBDC programs in the region and demonstrated inconsistencies in performance, when hosted by other organizations/agencies (M. Jackson, personal communication, September 10, 2020). However, in early 2019 the program was brought onto the Ohlone College campus to be integrated into the career center. This evaluation of the program was based on these changes to determine the impact this integration with the Ohlone College Tri-Cities Career Center has had on the program's performance (Sylvia and Sylvia, 2012).

As indicated by the Office of the Inspector General for the Small Business Administration (SBA), the Key Performance Indicators (KPIs) for the Small Business Development Center (SBDC) program are economic impact and customer satisfaction (Lee, 1998,7). These two KPIs served as the key indicators being used to determine the outcome of this research.

As discussed earlier, the work of past researchers on the evaluation of SBDC programs across the nation has provided a model based on best-practices and lessons learned for conducting this research (Chrisman et al., 1985, 1987; Elstrott, 1987; Lang \& Golden, 1989; Thompson et al., 1996). This research followed a two-tiered approach, a quasiexperimental approach and a non-experimental approach. 


\section{A. Quasi-Experimental:}

A quasi-experimental approach was used to understand the impact of the performance of the Alameda County Small Business Development Center (SBDC) program, before and after integrating into the Ohlone College Tri-Cities Career Center. As exhibited in previous research on this subject matter, a time-series design was implemented to analyze the impact the interventions of the Ohlone College Tri-Cities Career Center for integrating the Alameda County Small Business Development Center (SBDC) program have had on the program (Newell, 2018, 20).

The time-series design data was tracked from January $1^{\text {st }}, 2016$ to December $31^{\text {st }}$, 2020. As the fiscal year for the Small Business Development Center (SBDC) program runs on the same timeframe (calendar year), this data provided five years of continuous data on the Alameda County SBDC program. The key data points observed were for the total amount of capital funding, total counseling hours and total training event hours. These three data points provided a model to measure the success of an SBDC program, based on economic impact and customer satisfaction, the KPIs being used to determine the outcome of this research (Lee, 1998, 7).

The interventions were applied during February of 2019 through the end of the period in December 2020 and were not applied in the first three years of data.

\section{TABLE 1: Time-Series Design - By Fiscal Year}

\section{Time Series Design - By Fiscal Year for Capital Funding, Counseling \& Training Events} R1 O $\mathrm{O}$ $\mathrm{O}$ $\mathrm{XO}$ $\mathrm{XO}$

In Table 1, R1 represents any of the three data points that have been collected over this five-year period. The O's represent observations of these values without the 
interventions of Ohlone College (the period when the SBDC program was hosted by another organizations/agency). The X's represent observations of these values for fiscal years in which Ohlone's interventions were present.

\section{B. Non-Experimental:}

A non-experimental comparison of the performance of the Alameda County Small Business Development Center (SBDC) program at the Ohlone College Tri-Cities Career Center and other SBDC programs in the Northern California SBDC network with "similar resource mixes" was conducted (Lang \& Golden, 1989, 43).

The data for this research was derived from the Neoserra database for the Northern California SBDC Network, and from the Northern California SBDC Lead Center (Who We Are | Northern California SBDC Network, n.d.). 


\section{FINDINGS}

\section{A. Quasi-Experimental: Comparison of SBDC Performance Before \& After}

\section{Integration}

A quasi-experimental approach is used to understand how the integration of the Alameda County Small Business Development Center (SBDC) program into the Ohlone College TriCities Career Center has impacted the performance of the program.

The SBDC Program operates on a fiscal year that aligns with the calendar year (from January $1^{\text {st }}$ to December $\left.31^{\text {st }}\right)$. This research compares three data points of program performance that help measure economic impact and customer satisfaction, the two Key Performance Indicators (KPI's) established by the Office of the Inspector General for the Small Business Administration (SBA) (Lee, 1998, 7): total amount of capital funding, total counseling hours and total training event hours.

\section{TABLE 2: Time-Series Design - By Fiscal Year}

\section{Time Series Design - By Fiscal Year for Capital Funding, Counseling \& Training Events}

A time-series design was implemented (See Table 2) to analyze how the interventions of the Ohlone College Tri-Cities Career Center in integrating the Alameda County Small Business Development Center (SBDC) program have impacted the program (Newell, 2018, 20). R1 represents any of the three data points that have been collected over a five-year period between January $1^{\text {st }}, 2016$ and December $31^{\text {st }}, 2020$. The O's represent observations of these values without the interventions of Ohlone College (the period when the SBDC program was hosted by another organizations/agency). The X's represent observations of these values for 
fiscal years in which Ohlone's interventions were present. This data provided an insight into how the integration of the SBDC program into Ohlone's Career Center has had an impact on total capital funding (Table 3), total counseling hours (Table 4) and total training event hours (Table 5).

TABLE 3: Time-Series Design: Capital Funding - Alameda County SBDC

\begin{tabular}{|c|c|c|c|c|c|}
\hline \multicolumn{5}{|c|}{ Ohlone College Tri-Cities Career Center Interventions - Captial Funding } \\
\hline Year & 2016 & 2017 & 2018 & 2019 & 2020 \\
\hline Funding & $\$ 25,566,185.00$ & $\$ 10,933,801.06$ & $\$ 16,372,750.01$ & $\$ 21,340,756.00$ & $\$ 30,178,030.20$ \\
\hline
\end{tabular}

TABLE 4: Time-Series Design: Counseling - Alameda County SBDC

\begin{tabular}{|c|c|c|c|c|c|}
\hline \multicolumn{5}{|c|}{ Ohlone College Tri-Cities Career Center Interventions - Counseling } \\
\hline Year & 2016 & 2017 & 2018 & 2019 & 2020 \\
\hline Hours & 3,911 & 2,858 & 2,710 & 3,150 & 13,152 \\
\hline
\end{tabular}

TABLE 5: Time-Series Design: Training Events - Alameda County SBDC

\begin{tabular}{|c|c|c|c|c|c|}
\hline \multicolumn{5}{|c|}{ Ohlone College Tri-Cities Career Center Interventions - Training Events } \\
\hline Year & 2016 & 2017 & 2018 & 2019 & 2020 \\
\hline Hours & 3,920 & 5,088 & 4,075 & 4,491 & 8,696 \\
\hline
\end{tabular}




\section{B. Non-Experimental: Comparison of SBDC Programs with Similar Resource Mixes}

The purpose of the quasi-experimental tier of this research was to gain insight into whether the integration of the Alameda County Small Business Development Center (SBDC) program into the Ohlone College Tri-Cities Career Center has had an impact on the program's performance. Assuming that there was a measurable impact demonstrated by the Alameda County SBDC's performance over the five-year period, this tier of this research alone is not enough to substantiate the claim that such an integration would benefit any SBDC program in the region. Thus, this research requires a second tier - the nonexperimental tier.

The non-experimental tier of this research will compare the productivity of the Alameda County SBDC's program among other centers' programs in the Northern California SBDC Network, with "similar resource mixes" (Lang \& Golden, 1989, 43). The additional data for this tier of the research was collected from the Sonoma County SBDC program and the Contra Costa County SBDC program. This data consisted of figures for capital funding, counseling and training events and was derived from the Neoserra database for the Northern California SBDC Network, and from the Northern California SBDC Lead Center (Who We Are | Northern California SBDC Network, n.d.). 
TABLE 6: Alameda County SBDC - Capital Funding*

Alameda County SBDC - Capital Funding

\begin{tabular}{|l|l|}
\hline Year & Amount \\
\hline 2016 & $\$ 25,566,185.00$ \\
\hline 2017 & $\$ 10,933,801.06$ \\
\hline 2018 & $\$ 16,372,750.01$ \\
\hline 2019 & $\$ 21,340,756.00$ \\
\hline 2020 & $\$ 30,178,030.20$ \\
\hline
\end{tabular}

*Data values for funding coming from sources unrelated to SBDC have been ommitted in the final calculations.

\section{FIGURE 2: Alameda County SBDC - Capital Funding}

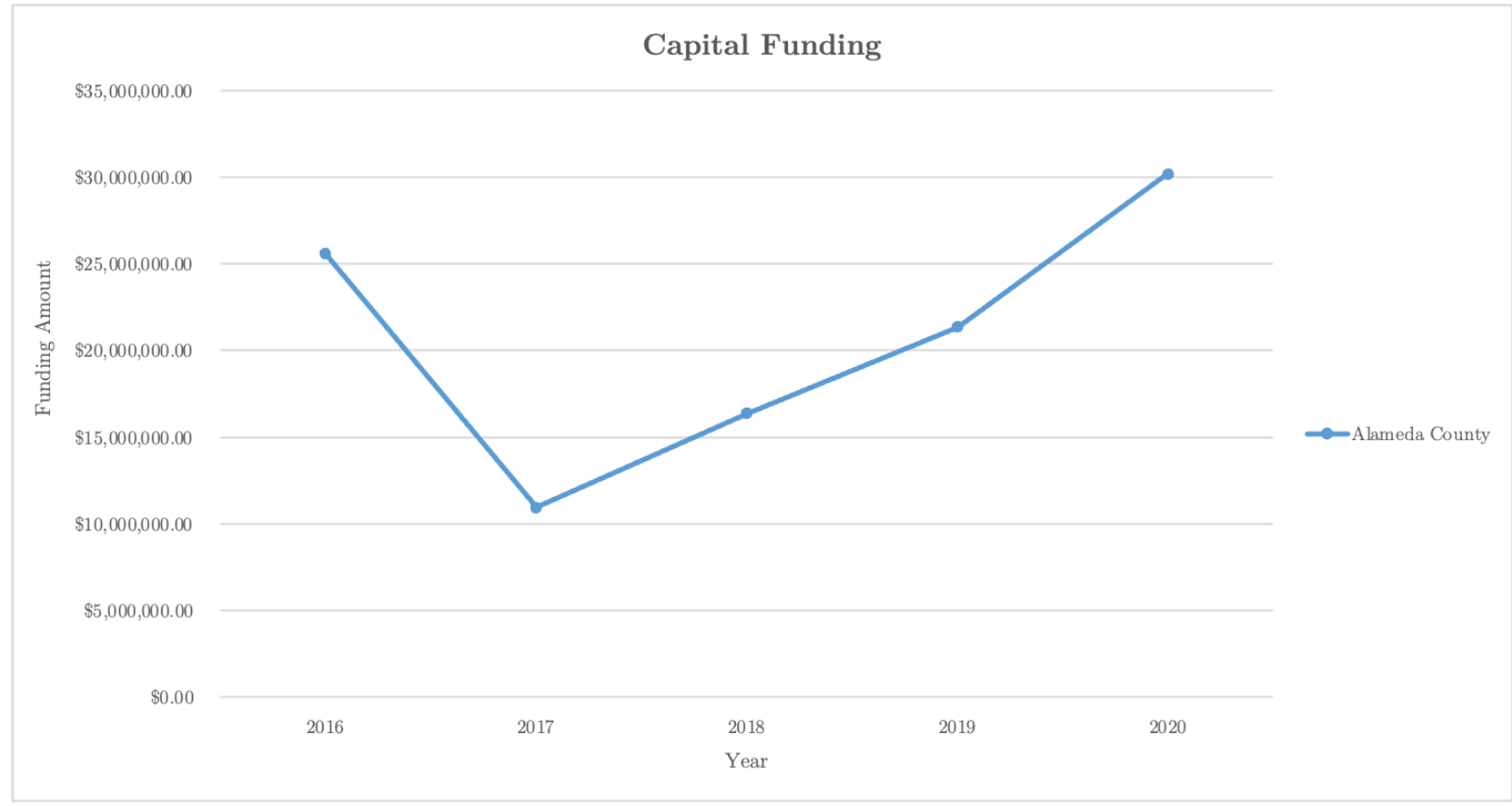

Table 6 and Figure 2 are based on data collected from the Northern California SBDC Neoserra

Database on the performance of the Alameda County SBDC program. An increase of $\$ 13.8$ million can be seen from the end of 2018 to the end of 2020 - an approximate $84 \%$ increase in funding since the integration of the program into Ohlone College. 
TABLE 7: Solano County SBDC - Capital Funding*

\section{Solano County SBDC - Capital Funding}

\begin{tabular}{|l|l|}
\hline Year & Amount \\
\hline 2016 & $\$ 2,687,960.00$ \\
\hline 2017 & $\$ 4,088,572.00$ \\
\hline 2018 & $\$ 2,332,687.00$ \\
\hline 2019 & $\$ 4,106,787.65$ \\
\hline 2020 & $\$ 8,926,602.00$ \\
\hline
\end{tabular}

* Data values for funding coming from sources unrelated to SBDC have been ommitted in the final calculations.

\section{FIGURE 3: Solano County SBDC - Capital Funding}

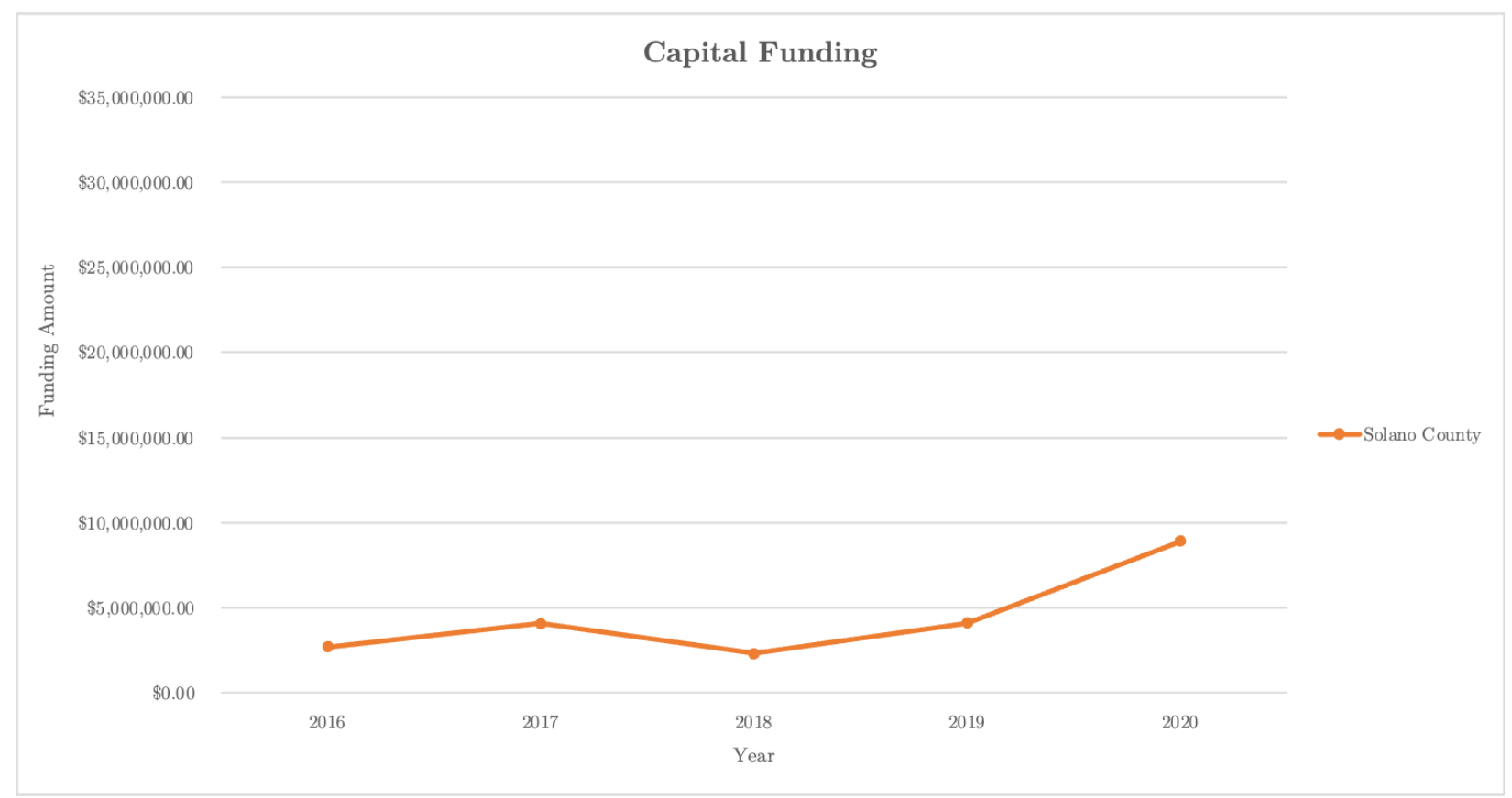

Table 7 and Figure 3 are based on data collected from the Northern California SBDC Neoserra Database on the performance of the Solano County SBDC program. A slight fluctuation in capital funding can be seen between 2016 and 2019 with a larger increase between 2019 and 2020 of $\$ 4.8$ million. 
TABLE 8: Contra Costa County SBDC - Capital Funding*

Contra Costa County - Capital Funding

\begin{tabular}{|l|r|}
\hline Year & Amount \\
\hline 2016 & $\$ 6,547,630.17$ \\
\hline 2017 & $\$ 6,563,550.08$ \\
\hline 2018 & $\$ 5,748,135.00$ \\
\hline 2019 & $\$ 3,687,790.00$ \\
\hline 2020 & $\$ 24,077,652.19$ \\
\hline
\end{tabular}

*Data values for funding coming from sources unrelated to SBDC have been ommitted in the final calculations.

FIGURE 4: Contra Costa County SBDC - Capital Funding

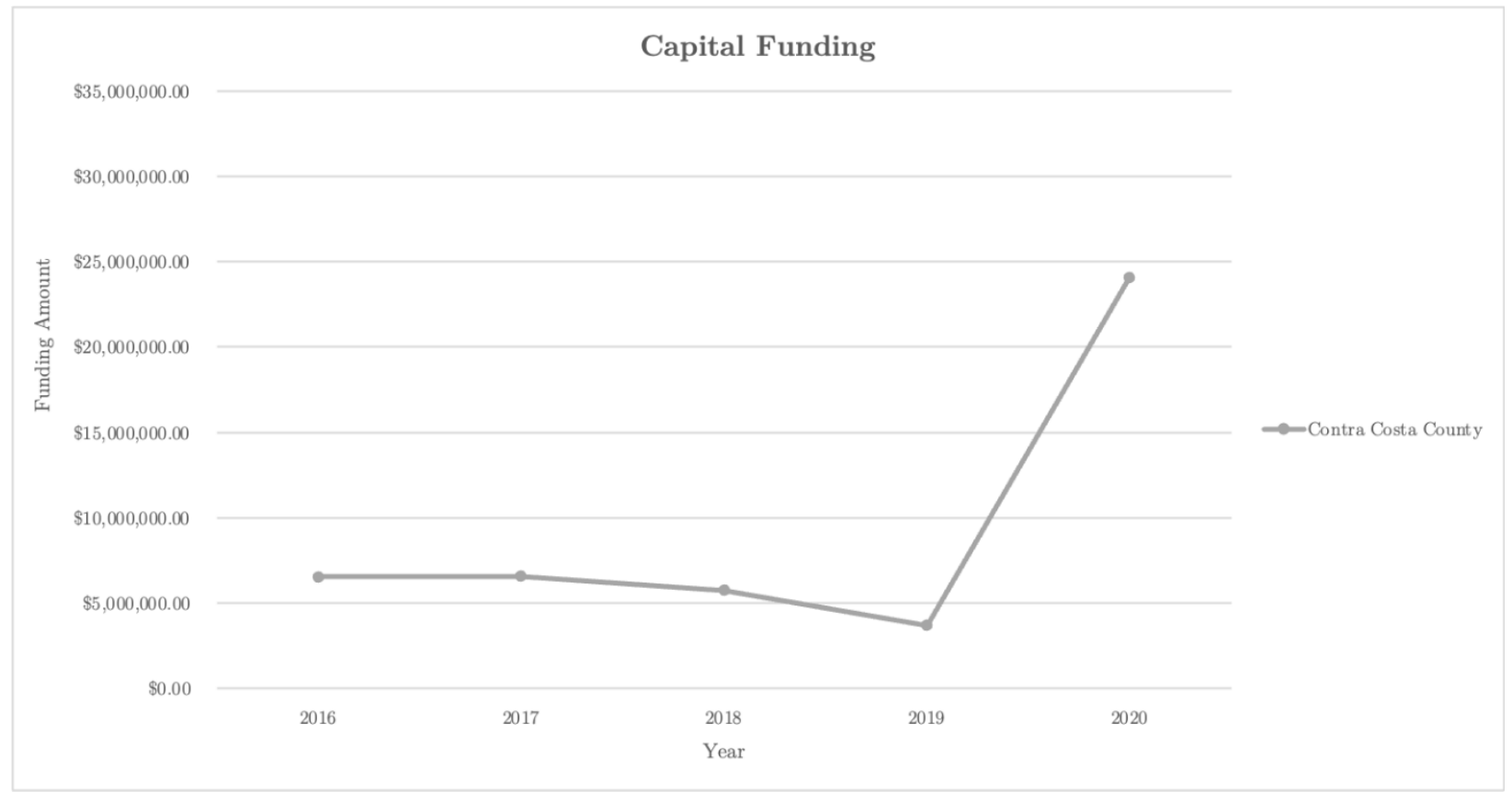

Table 8 and Figure 4 are based on data collected from the Northern California SBDC Neoserra Database on the performance of the Contra Costa County SBDC program. An overall downward trend in capital funding can be seen between 2016 and 2019 with a sudden increase in 2020 by about $\$ 20$ million. 
TABLE 9: Alameda County SBDC - Counseling

Alameda County SBDC - Counseling
\begin{tabular}{|l|r|}
\hline Year & Total Hours \\
\hline 2016 & 3,911 \\
\hline 2017 & 2,858 \\
\hline 2018 & 2,710 \\
\hline 2019 & 3,150 \\
\hline 2020 & 13,152 \\
\hline
\end{tabular}

FIGURE 5: Alameda County SBDC - Counseling

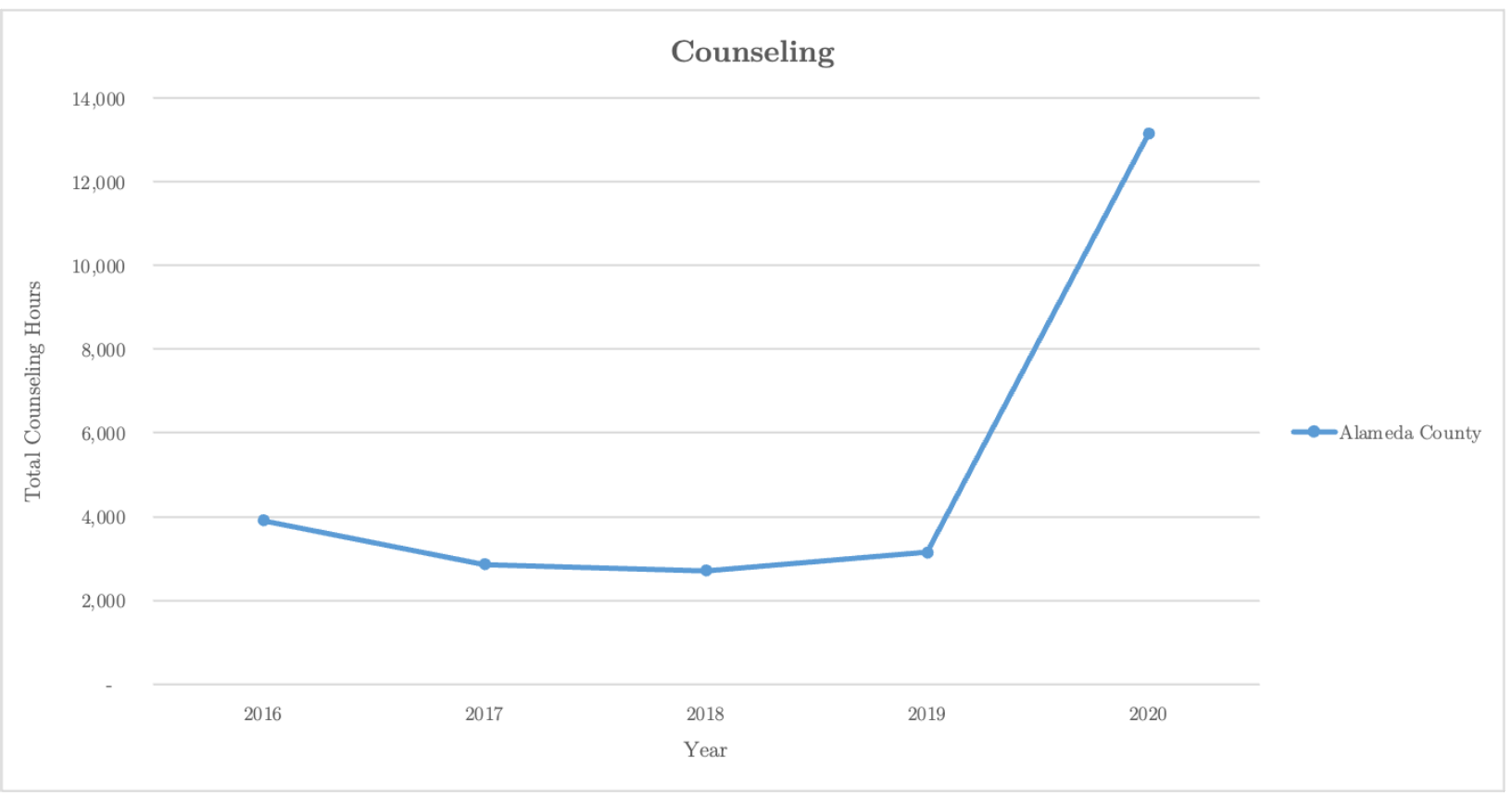

Table 9 and Figure 5 are based on data collected from the Northern California SBDC Neoserra Database on the performance of the Alameda County SBDC program. An increase of 10,442 counseling hours can be seen from the end of 2018 to the end of 2020 - an approximate $385 \%$ increase in counseling hours since the integration of the program into Ohlone College. 
TABLE 10: Solano County SBDC - Counseling

\begin{tabular}{|l|r|}
\begin{tabular}{|l|r|}
\multicolumn{2}{|c|}{ Solano County SBDC - Counseling } \\
\hline Year & Total Hours \\
\hline 2016 & 828 \\
\hline 2017 & 611 \\
\hline 2018 & 552 \\
\hline 2019 & 1,221 \\
\hline 2020 & 3,155 \\
\hline
\end{tabular}
\end{tabular}

FIGURE 6: Solano County SBDC - Counseling

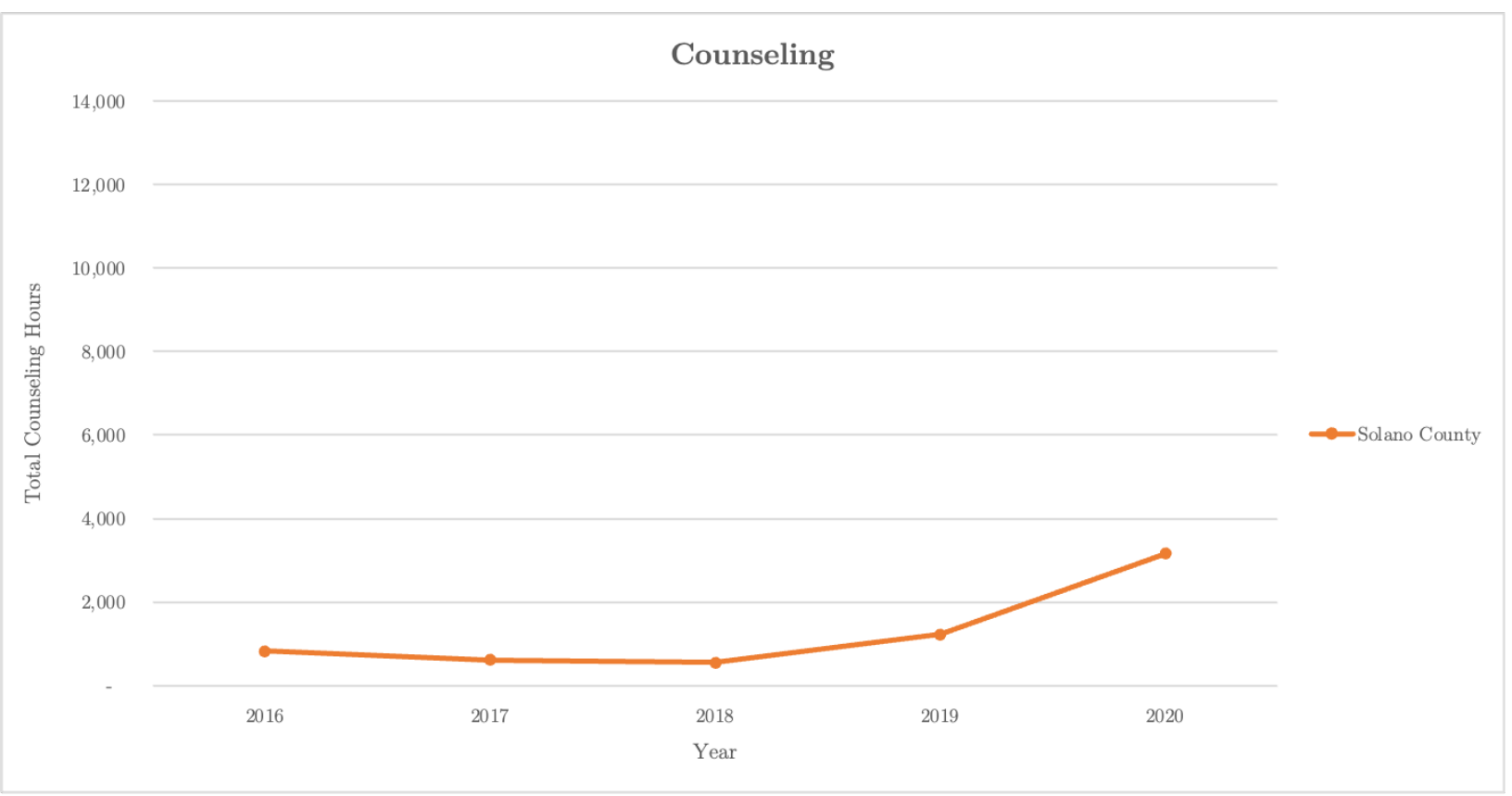

Table 10 and Figure 6 are based on data collected from the Northern California SBDC Neoserra Database on the performance of the Solano County SBDC program. An overall increase in counseling hours can be seen for this center, with a larger increase between 2019 and 2020 by 1,934 counseling hours. 
TABLE 11: Contra Costa County SBDC - Counseling

Contra Costa County SBDC - Counseling
\begin{tabular}{|l|r|}
\hline Year & Total Hours \\
\hline 2016 & \\
\hline 2017 & 4,181 \\
\hline 2018 & 3,482 \\
\hline 2019 & 3,346 \\
\hline 2020 & 2,703 \\
\hline
\end{tabular}

FIGURE 7: Contra Costa County SBDC - Counseling

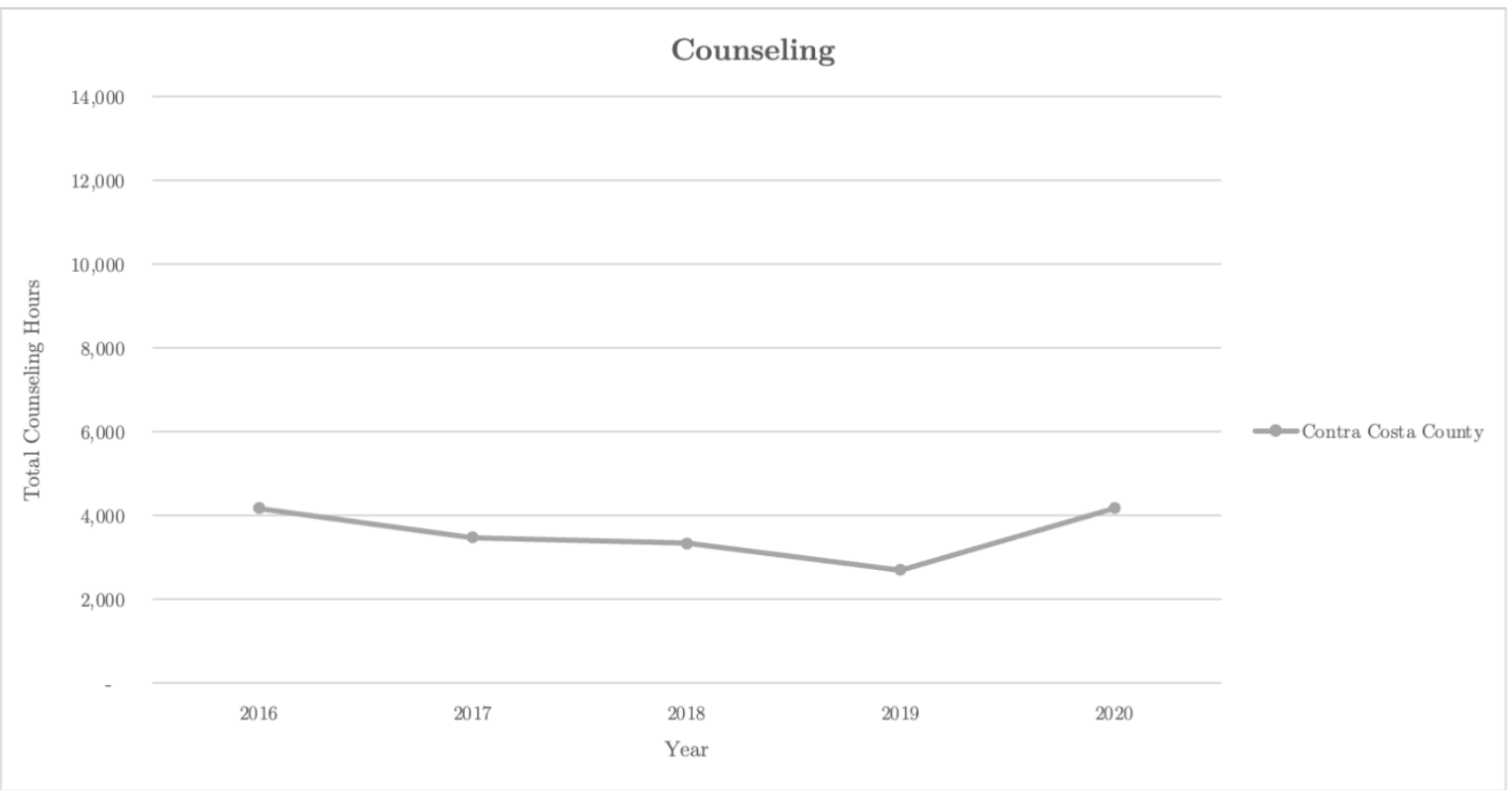

Table 11 and Figure 7 are based on data collected from the Northern California SBDC Neoserra Database on the performance of the Contra Costa County SBDC program. An overall downward trend in counseling hours can be seen for this center, followed by a significant increase in the last year from $2019-2020$ by about 1,473 counseling hours, bringing it close to the original peak in 2016 of 4,181 counseling hours. 
TABLE 12: Alameda County SBDC - Training Events*

\begin{tabular}{l}
\multicolumn{1}{|c|}{ Alameda County SBDC - Training Events } \\
\begin{tabular}{|l|r|} 
Year & Total Training Hours \\
\hline 2016 & 3,920 \\
\hline 2017 & 5,088 \\
\hline 2018 & 4,075 \\
\hline 2019 & 4,491 \\
\hline 2020 & 8,696 \\
\hline
\end{tabular}
\end{tabular}

*Data values for events associated with a fee and events entered as greater than 12 hours per day, were omitted in the final calculations.

\section{FIGURE 8: Alameda County SBDC - Training Events}

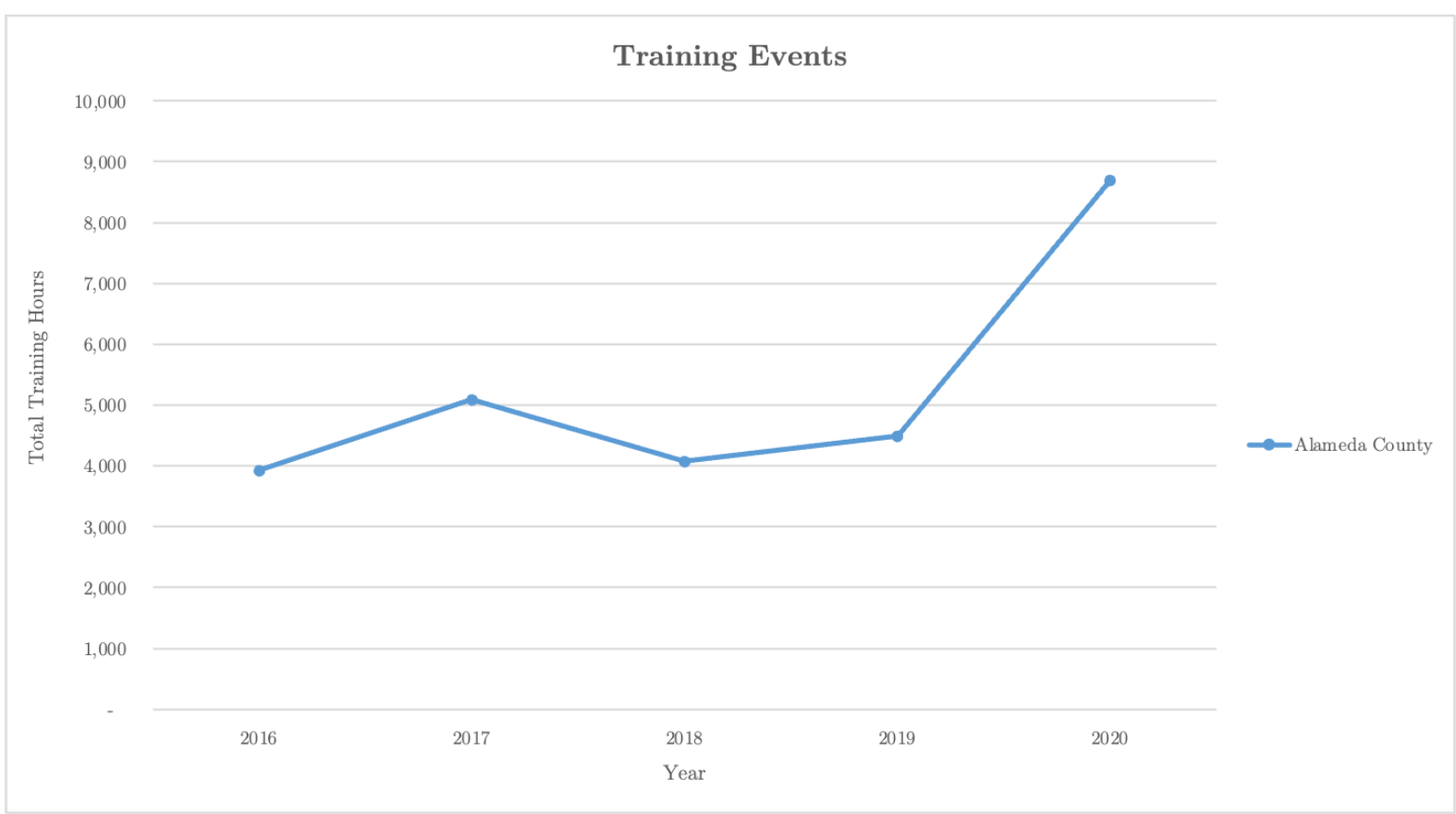

Table 12 and Figure 8 are based on data collected from the Northern California SBDC Neoserra

Database on the performance of the Alameda County SBDC program. An increase of 4,621 training event hours can be seen from the end of 2018 to the end of 2020 - an approximate $113 \%$ increase in training event hours since the integration of the program into Ohlone College. 
TABLE 13: Solano County SBDC - Training Events*

Solano County SBDC - Training Events
\begin{tabular}{|l|r|} 
Year & Total Training Hours \\
\hline 2016 & 1,170 \\
\hline 2017 & 850 \\
\hline 2018 & 853 \\
\hline 2019 & 988 \\
\hline 2020 & 1,772 \\
\hline
\end{tabular}

*Data values for events associated with a fee and events entered as greater than 12 hours per day, were omitted in the final calculations.

FIGURE 9: Solano County SBDC - Training Events

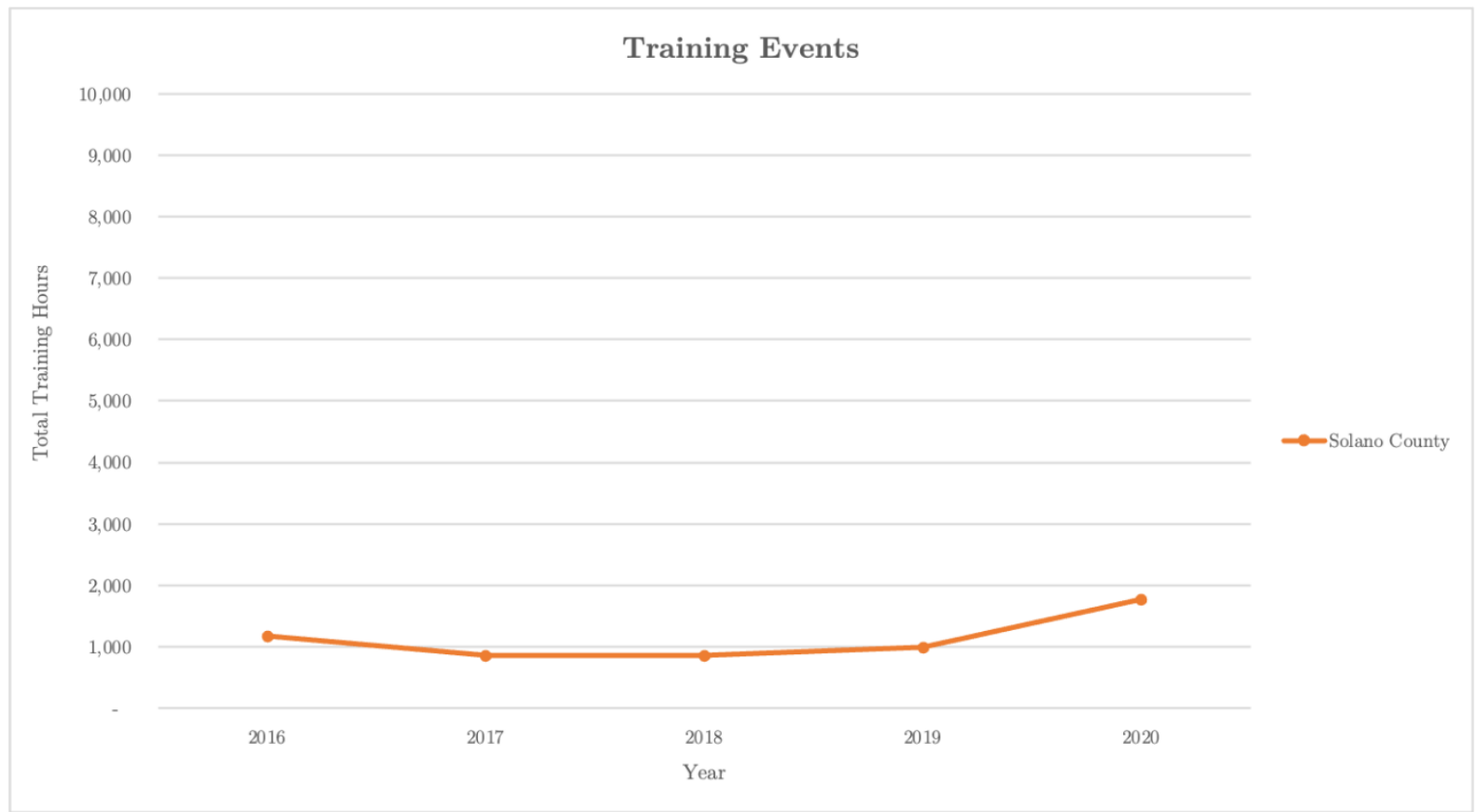

Table 13 and Figure 9 are based on data collected from the Northern California SBDC Neoserra Database on the performance of the Solano County SBDC program. After an approximate 27\% decrease in training event hours between 2016 and 2017, an overall level trend with few fluctuations can be seen until the end of 2019. This is followed by an increase by $18.6 \%$, bringing the total training event hours back to the 2016 peak of 1,170 hours. 
TABLE 14: Contra Costa County SBDC - Training Events* Contra Costa County SBDC - Training Events

\begin{tabular}{|l|r|}
\hline Year & Total Training Hours \\
\hline 2016 & 2,704 \\
\hline 2017 & 2,347 \\
\hline 2018 & 1,504 \\
\hline 2019 & 1,451 \\
\hline 2020 & 707 \\
\hline
\end{tabular}

*Data values for events associated with a fee and events entered as greater than 12 hours per day, were omitted in the final calculations.

FIGURE 10: Contra Costa County SBDC - Training Events

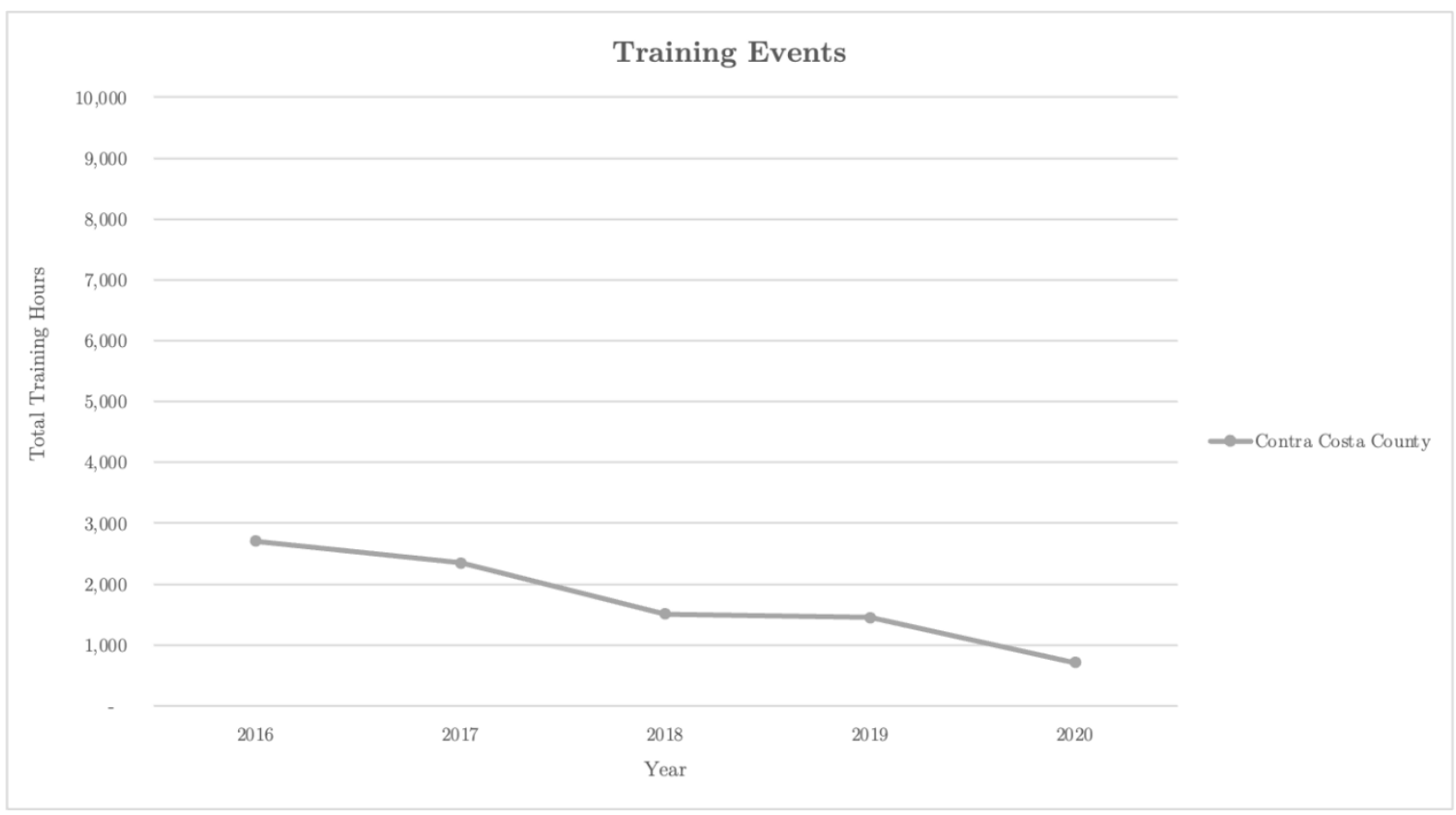

Table 14 and Figure 10 are based on data collected from the Northern California SBDC Neoserra Database on the performance of the Contra Costa County SBDC program. A continuous decrease by about $74 \%$ in training event hours can be seen for this center between 2016 and 2020. 


\section{$\underline{\text { ANALYSIS }}$}

This analysis will first outline and discuss the quasi-experimental comparison of the SBDC's performance before and after the integration into Ohlone's Career Center and will then be followed by a discussion of the non-experimental comparison of the Alameda County SBDC program and two other SBDC programs in the Northern California region with "similar resource mixes:" the Solano County SBDC program and the Contra Costa County SBDC program.

\section{A. Quasi-Experimental: Comparison of SBDC Program Performance Before \& After Integration}

This research reviews whether the interventions of integrating the Alameda County Small Business Development Center (SBDC) program into the Ohlone College Tri-Cities Career Center had in impact on the performance of the SBDC program.

\section{TABLE 15: Time-Series Design - By Fiscal Year}

\section{Time Series Design - By Fiscal Year for Capital Funding, Counseling \& Training Events

As seen in Table 15, R1 represents any of the three data points that have been collected over a five-year period between January $1^{\text {st }}, 2016$ and December $31^{\text {st }}, 2020$. The O's indicate observations for fiscal years without the interventions of Ohlone College (the period when the SBDC program was hosted by another organizations/agency). The X's indicate observations for fiscal years in which Ohlone's interventions were present. This time-series design provided an insight into how the integration of the SBDC program into Ohlone's Career Center has had an impact on total capital funding, total counseling hours and total training event hours. 
TABLE 16: Time-Series Design: Capital Funding - Alameda County SBDC

\begin{tabular}{|c|c|c|c|c|c|}
\hline \multicolumn{6}{|c|}{ Ohlone College Tri-Cities Career Center Interventions - Captial Funding } \\
\hline Year & 2016 & 2017 & 2018 & 2019 & 2020 \\
\hline Funding & $\$ 25,566,185.00$ & $\$ 10,933,801.06$ & $\$ 16,372,750.01$ & $\$ 21,340,756.00$ & $\$ 30,178,030.20$ \\
\hline
\end{tabular}

Table 16 outlines the capital funding data collected for the Alameda County SBDC program between January $1^{\text {st }}, 2016$ and December $31^{\text {st }}, 2020$. Based on the data provided, it is clear that there has been a downward trend in capital funding over the years the SBDC program was hosted by other organizations/sites. As soon as the program was taken over by the Tri-Cities Career Center at Ohlone College, the amount of capital funding for small business clients for the county has consistently increased. From 2018 to 2019 (when the program was taken over by Ohlone) there was an increase of $\$ 4,968,015$ in capital funding (an approximate $30 \%$ increase). This was then followed by another increase of $\$ 8,837,274-$ nearly a $41 \%$ increase in capital funding. The total increase in capital funding during the time period of integration (between the end of 2018 to the end of 2020) is calculated out to be nearly $84 \%$.

\section{TABLE 17: Time-Series Design: Counseling - Alameda County SBDC}

\begin{tabular}{|c|c|c|c|c|c|}
\hline \multicolumn{6}{|c|}{ Ohlone College Tri-Cities Career Center Interventions - Counseling } \\
\hline Year & 2016 & 2017 & 2018 & 2019 & 2020 \\
\hline Hours & 3,911 & 2,858 & 2,710 & 3,150 & 13,152 \\
\hline
\end{tabular}

Table 17 outlines the counseling data collected for the Alameda County SBDC program between January $1^{\text {st }}, 2016$ and December $31^{\text {st }}, 2020$. The data demonstrates a consistent downward trend in counseling hours over the years the SBDC program was hosted by other organizations/sites, between the years of 2016 and 2018. This consistent decrease is 
then followed by a consistent increase from 2018 to 2020 (when the program was taken over by Ohlone). Between 2018 and 2019, counseling hours increased by 440 hours (an approximate $16 \%$ increase). This small increase is then followed by a surge in counseling hours by about 10,000 counseling hours - a 318\% increase. The total increase in counseling hours during the time period of integration (between the end of 2018 to the end of 2020) is calculated out to be nearly $385 \%$.

\section{TABLE 18: Time-Series Design: Training Events - Alameda County SBDC}

\begin{tabular}{|c|c|c|c|c|c|}
\hline \multicolumn{5}{|c|}{ Ohlone College Tri-Cities Career Center Interventions - Training Events } \\
\hline Year & 2016 & 2017 & 2018 & 2019 & 2020 \\
\hline Hours & 3,920 & 5,088 & 4,075 & 4,491 & 8,696 \\
\hline
\end{tabular}

Table 18 displays the training event data collected for the Alameda County SBDC program between January $1^{\text {st }}, 2016$ and December $31^{\text {st }}, 2020$. The data demonstrates a significant fluctuation in the total training event hours (total hours of training multiplied by attendees), between the years of 2016 and 2018. This fluctuation is then followed by a consistent increase from 2018 to 2020 (when the program was taken over by Ohlone). Between 2018 and 2019, there was a slight increase in training event hours by 416 hours (an approximate $10 \%$ increase). This small increase, however, is then followed by a larger increase in training event hours - similar to that in counseling hours (See Table 18) - by 4,205 hours - a 94\% increase. The total increase in training event hours during the time period of integration (between the end of 2018 to the end of 2020) is calculated out to be nearly $113 \%$. 


\section{i. Interventions Made by Ohlone College in the Integration of the Alameda County SBDC Program into the Tri-Cities Career Center:}

The Ohlone College Tri-Cities Career Center officially became the host of the Alameda County Small Business Development Center (SBDC) program in January of 2019 (Our Host: Ohlone College | Alameda SBDC, n.d.). Since then, the center has taken a few steps to integrate the program and its services into the center's existing menu of services ( $\mathrm{J}$. Jimenez, personal communication, October 16, 2020).

One of the first steps taken in this integration process, was a change in staffing (About Us - Career Center, 2018; J. Jimenez, personal communication, October 16, 2020). With the SBDC program in place, the center now needed support to provide these new services. Thus, the center hired for two new roles: a program director and a programs specialist (About Us - Career Center, 2018). In addition to the new hires, the center also made changes to the job description for an existing role. The "Job Developer" role, which was previously responsible for working with employers and developing new job opportunities for students and other clients of the career center (among other duties), was now transitioned to an "Employer \& Entrepreneurship Advisor" (EEA) role (J. Jimenez, personal communication, October 16, 2020). This new role included all of the existing responsibilities listed in the old job description, but included providing administrative support, business advising and other forms of support for the new SBDC program (Employer and Entrepreneurship Advisor Job Description | Ohlone College, 2019; J. Jimenez, personal communication, October 16, 2020). 
With a new staff and new job descriptions for existing staff, the center also needed a restructure. The center is now split into three groups/teams (J. Jimenez, personal communication, October 16, 2020):

\section{- Administration and Operations}

○ Director, Career Center \& Alameda County SBDC

○ Program Manager, Entrepreneurship and Employer Services

- This is a new role that replaces the original Program Director role for the Alameda County SBDC program. The new Program Manager now also oversees the Employer \& Entrepreneurship Services team in addition to the SBDC program (D. Newell, personal communication, March 24, 2021)

○ Program Manager, Career Development

- This is also a new role that is currently being developed to better structure the organization. Although this role has not officially been filled yet, the individual in this role would oversee the Career Development team and support the Director (D. Newell, personal communication, March 24, 2021).

- Program Specialists (2)

\section{- Career Development}
- Career Advisors (3)
- Career Advisor Intern (As needed)
$\circ$ Other partners

\section{- Employer \& Entrepreneurship Services}

- Employer \& Entrepreneurship Services Advisors (2) 
- Employer \& Entrepreneurship Services Intern (As needed)

- SBDC Entrepreneurship Consultants (SBDC Business Advisors)

- Other partners

This new structure for the center provided better organization, with each "team" having its own meetings to plan out upcoming events and discuss strategies to meet center goals (J. Jimenez, personal communication, October 16, 2020).

The next major step taken in this integration process was programming. The new employer and entrepreneurship services team was charged with finding new and innovative ways of aligning common goals that could be achieved through existing and new programs. One such example of a new program that was developed by this team was the "microinternship" program (A. Ambrocio, personal communication, January 19, 2021). In coordination with the career services team, the center was able to develop a microinternship program that provided businesses with an intern to support their business, fully paid for through the Workforce Innovation and Opportunity Act (WIOA) program under the Alameda County Workforce Development Board (ACWDB) (A. Ambrocio, personal communication, January 19, 2020). The launch of such an innovative program serves as a testament to the types of interventions that were made by Ohlone College in the integration of the Alameda County SBDC program, explaining the increases in all three values that were measured by this research - capital funding, counseling and training events.

This restructure and change in programming led to the development of a new Program Logic Model (PLM) for the SBDC program (See Table 22), to track the goals and points of engagement with various stakeholders for the Alameda County SBDC 
program (J. Jimenez, personal communication, October 16, 2020). This new PLM is similar to the existing PLM's for Outreach and Enrollment (See Table 19), Career Development (See Table 20) and Employer Engagement (See Table 21) (Newell, 2018, $51)$. 
TABLE 19: Program Logic Model (PLM) - Outreach \& Enrollment*

*Adapted from research done on Ohlone College's Career Center by Newell (2018).

\begin{tabular}{|c|c|c|c|c|}
\hline Inputs & Activities & Outputs & $\begin{array}{l}\text { Outcomes } \\
\text { (Tier 1) }\end{array}$ & $\begin{array}{l}\text { Outcomes } \\
\text { (Tier 2) }\end{array}$ \\
\hline $\begin{array}{l}\text { Time (Hours) } \\
\text { Department } \\
\text { Expenses }\end{array}$ & $\begin{array}{l}\text { Student Meetings } \\
\text { Community Meetings } \\
\text { Presentation/Workshops } \\
\text { Other Event Planning } \\
\text { Luncheons/Banquets } \\
\text { Media/Press Training } \\
\text { Cold Calling } \\
\text { Email Blasts } \\
\text { R\&D Activities } \\
\text { Curriculum/Content } \\
\text { Development } \\
\text { Fiscal Management }\end{array}$ & $\begin{array}{l}\text { Number of } \\
\text { Orientations } \\
\text { Number of } \\
\text { Workshops } \\
\text { Number of } \\
\text { Traffic } \\
\text { Number of } \\
\text { Orientation } \\
\text { Attendees } \\
\text { Number of } \\
\text { Workshop } \\
\text { Attendees } \\
\text { Number of } \\
\text { Event } \\
\text { Attendees }\end{array}$ & $\begin{array}{l}\text { Number of } \\
\text { Applications } \\
\text { Received } \\
\text { Number of } \\
\text { Applications } \\
\text { Processed }\end{array}$ & $\begin{array}{l}\text { Number of } \\
\text { Adult Priority } \\
\text { Enrollments } \\
\text { Number of } \\
\text { Adult Non- } \\
\text { Priority } \\
\text { Enrollments } \\
\text { Number of } \\
\text { Dislocated } \\
\text { Worker } \\
\text { Enrollments } \\
\text { Number of } \\
\text { Student } \\
\text { Enrollments } \\
\text { Number of } \\
\text { Students } \\
\text { Processed }\end{array}$ \\
\hline
\end{tabular}


TABLE 20: Program Logic Model (PLM) - Career Development**

*Adapted from research done on Ohlone College's Career Center by Newell (2018).

\begin{tabular}{|c|c|c|c|c|}
\hline Inputs & Activities & Outputs & $\begin{array}{l}\text { Outcomes } \\
\text { (Tier 1) }\end{array}$ & $\begin{array}{l}\text { Outcomes } \\
\text { (Tier 2) }\end{array}$ \\
\hline $\begin{array}{l}\text { Time (Hours) } \\
\text { Department } \\
\text { Expenses }\end{array}$ & $\begin{array}{l}\text { Meet with clients } \\
\text { Meet with community } \\
\text { partners } \\
\text { Develop Curriculum } \\
\text { Case Management } \\
\text { Client/Student Outreach } \\
\text { Professional } \\
\text { Development } \\
\text { Audit Preparation } \\
\text { Compile Reports }\end{array}$ & $\begin{array}{l}\begin{array}{l}\text { Number of } \\
\text { student/client } \\
\text { appointments }\end{array} \\
\text { Number of } \\
\text { Workshops } \\
\text { Number of } \\
\text { Attendees at } \\
\text { Workshops } \\
\text { Number of } \\
\text { Clients in } \\
\text { Caseload } \\
\text { Number of } \\
\text { Approved ITA } \\
\text { Number of } \\
\text { Approved OJT } \\
\text { Number of } \\
\text { Mentor/Mentee } \\
\text { Matches } \\
\text { Number of } \\
\text { Mentorship } \\
\text { Events }\end{array}$ & $\begin{array}{l}\text { Number of } \\
\text { ITA } \\
\text { Completed } \\
\text { Number of } \\
\text { OJT } \\
\text { Completed } \\
\text { ITA/OJT } \\
\text { Spending } \\
\text { Number of } \\
\text { Client } \\
\text { Interviews } \\
\text { Mentee } \\
\text { Matches } \\
\text { (Students) } \\
\text { Mentor } \\
\text { Matches } \\
\text { Percentage of } \\
\text { Student } \\
\text { Satisfaction } \\
\text { Rate }\end{array}$ & $\begin{array}{l}\text { Employment } \\
\text { Outcomes }\end{array}$ \\
\hline
\end{tabular}


TABLE 21: Program Logic Model (PLM) - Employer Engagement*

*Adapted from research done on Ohlone College's Career Center by Newell (2018).

\begin{tabular}{|c|c|c|c|c|}
\hline Inputs & Activities & Outputs & $\begin{array}{l}\text { Outcomes } \\
\text { (Tier 1) }\end{array}$ & $\begin{array}{l}\text { Outcomes } \\
\text { (Tier 2) }\end{array}$ \\
\hline $\begin{array}{l}\text { Time } \\
\text { (Hours) } \\
\text { Department } \\
\text { Expenses }\end{array}$ & $\begin{array}{l}\text { Employer } \\
\text { Consultations } \\
\text { Student Meetings } \\
\text { Community meetings } \\
\text { Trainings } \\
\text { Mixers (Attendees) } \\
\text { Mixers (Tabling) } \\
\text { Luncheons/Banquets } \\
\text { Media/Press } \\
\text { Collateral Creation } \\
\text { Presentation/Workshop } \\
\text { Creation } \\
\text { Conferences/Summits } \\
\text { Event Planning } \\
\text { Marketing \& Outreach } \\
\text { R\&D Activities }\end{array}$ & $\begin{array}{l}\text { \# Employer Orientations } \\
\text { \# Employer Reps at } \\
\text { Orientations } \\
\text { \# New Employer } \\
\text { organizations in Job } \\
\text { Board } \\
\text { \# New Employer Reps in } \\
\text { Job Board } \\
\text { \# Job Postings on Job } \\
\text { Board } \\
\text { \# info-sessions } \\
\text { \#employer reps and } \\
\text { students at info-sessions } \\
\text { \# job fairs } \\
\text { \# employer reps and } \\
\text { students at job fair } \\
\text { \# Drop-In Interviews } \\
\text { (DII) } \\
\text { \# DII Employers } \\
\text { \# DII Students } \\
\text { \# Approved OJTs } \\
\text { \# Staffing services job } \\
\text { orders } \\
\text { \# Employer tabling events } \\
\text { \# Students visiting tables } \\
\text { \# Employer Reps at tables } \\
\text { \# Employer } \\
\text { Workshops/trainings } \\
\text { \# Employer attendees } \\
\text { \# Employers registered as } \\
\text { sponsors }\end{array}$ & $\begin{array}{l}\text { Number of } \\
\text { Interviews } \\
\text { (On- } \\
\text { Campus } \\
\text { Interviews) } \\
\text { Amount of } \\
\text { revenue } \\
\text { raised (\$) } \\
\text { Percentage } \\
\text { of student } \\
\text { satisfaction } \\
\text { rate } \\
\text { Percentage } \\
\text { of } \\
\text { employer } \\
\text { satisfaction } \\
\text { rate }\end{array}$ & $\begin{array}{l}\text { Number of } \\
\text { Employment } \\
\text { Outcomes }\end{array}$ \\
\hline
\end{tabular}


TABLE 22: *NEW* Program Logic Model (PLM) - Entrepreneurship Services (SBDC)*

*(J. Jimenez, personal communication, October 16, 2020)

\begin{tabular}{|c|c|c|c|c|}
\hline Inputs & Activities & Outputs & Outcomes (Tier 1) & $\begin{array}{l}\text { Outcomes } \\
\text { (Tier 2) }\end{array}$ \\
\hline $\begin{array}{l}\text { Time } \\
\text { (Hours) } \\
\text { Department } \\
\text { Expenses }\end{array}$ & $\begin{array}{l}\text { Research } \\
\text { Event Planning } \\
\text { Advising } \\
\text { Marketing \& } \\
\text { Outreach } \\
\text { Staff Professional } \\
\text { Development } \\
\text { Compile Reports } \\
\text { Consultant Hire } \\
\text { Develop } \\
\text { Curriculum/Content } \\
\text { Meetings/Interactions } \\
\text { with: students, } \\
\text { funders, partners, } \\
\text { Ohlone partners, } \\
\text { consultants, } \\
\text { employers and } \\
\text { business owners } \\
\text { Intake/Assign }\end{array}$ & $\begin{array}{l}\text { Advising } \\
\text { Appointments } \\
\text { (Ohlone } \\
\text { students, } \\
\text { Alumni, } \\
\text { Clients and } \\
\text { Others) } \\
\text { Workshops } \\
\text { Workshop } \\
\text { Attendees } \\
\text { (Ohlone } \\
\text { students, } \\
\text { Alumni, } \\
\text { Clients and } \\
\text { Others) } \\
\text { Enrollments } \\
\text { (Non-credit } \\
\text { Ohlone } \\
\text { courses) } \\
\text { Enrollments } \\
\text { WIOA } \\
\text { (referred by } \\
\text { SBDC) }\end{array}$ & $\begin{array}{l}\text { Increased Sales (Students, } \\
\text { Alumni, Clients, and } \\
\text { Others) } \\
\text { New Business Starts } \\
\text { (Students, Alumni, } \\
\text { Clients, and Others) } \\
\text { Access to Capital } \\
\text { (Students, Alumni, } \\
\text { Clients, and Others) } \\
\text { Jobs Creation (Students, } \\
\text { Alumni, Clients, and } \\
\text { Others) } \\
\text { Jobs Support (Students, } \\
\text { Alumni, Clients, and } \\
\text { Others) } \\
\text { Apportionment } \\
\text { Paid Training } \\
\text { OJT } \\
\text { OJT Amount } \\
\text { Jobs Filled } \\
\text { Internships Created } \\
\text { Satisfaction } \\
\text { Learning Outcomes }\end{array}$ & $\begin{array}{l}\text { Number of } \\
\text { Non- } \\
\text { Ohlone } \\
\text { Certificates } \\
\text { Received } \\
\text { Number of } \\
\text { Ohlone } \\
\text { Certificates } \\
\text { Received }\end{array}$ \\
\hline
\end{tabular}




\section{B. Non-Experimental: Comparison of SBDC Programs with Similar Resource Mixes}

This analysis discusses the comparisons of the Alameda County Small Business

Development Center (SBDC) program and two other SBDC programs in the Northern

California Region with similar resource mixes: the Solano County SBDC program and the Contra Costa SBDC program. These comparisons have used data collected over a five-year period from January $1^{\text {st }}, 2016$ to December $31^{\text {st }}, 2020$ for three key data points that have been identified to measure the Key Performance Indicators (KPI's) of this research (economic impact and customer satisfaction):

- Capital Funding Data

- Counseling Data

- Training Event Data

This non-experimental portion of this research provides a second tier of analysis required to better understand the impact of the integration on the productivity of the Alameda County SBDC program, in the context of other SBDC programs in the region. With this context, any increases or decreases in productivity can be better attributed to the impact of the integration of the SBDC program and not to other external factors. 
FIGURE 11: Capital Funding Data - Alameda, Solano and Contra Costa SBDC

* Data values for funding coming from sources unrelated to SBDC have been ommitted in the final calculations.

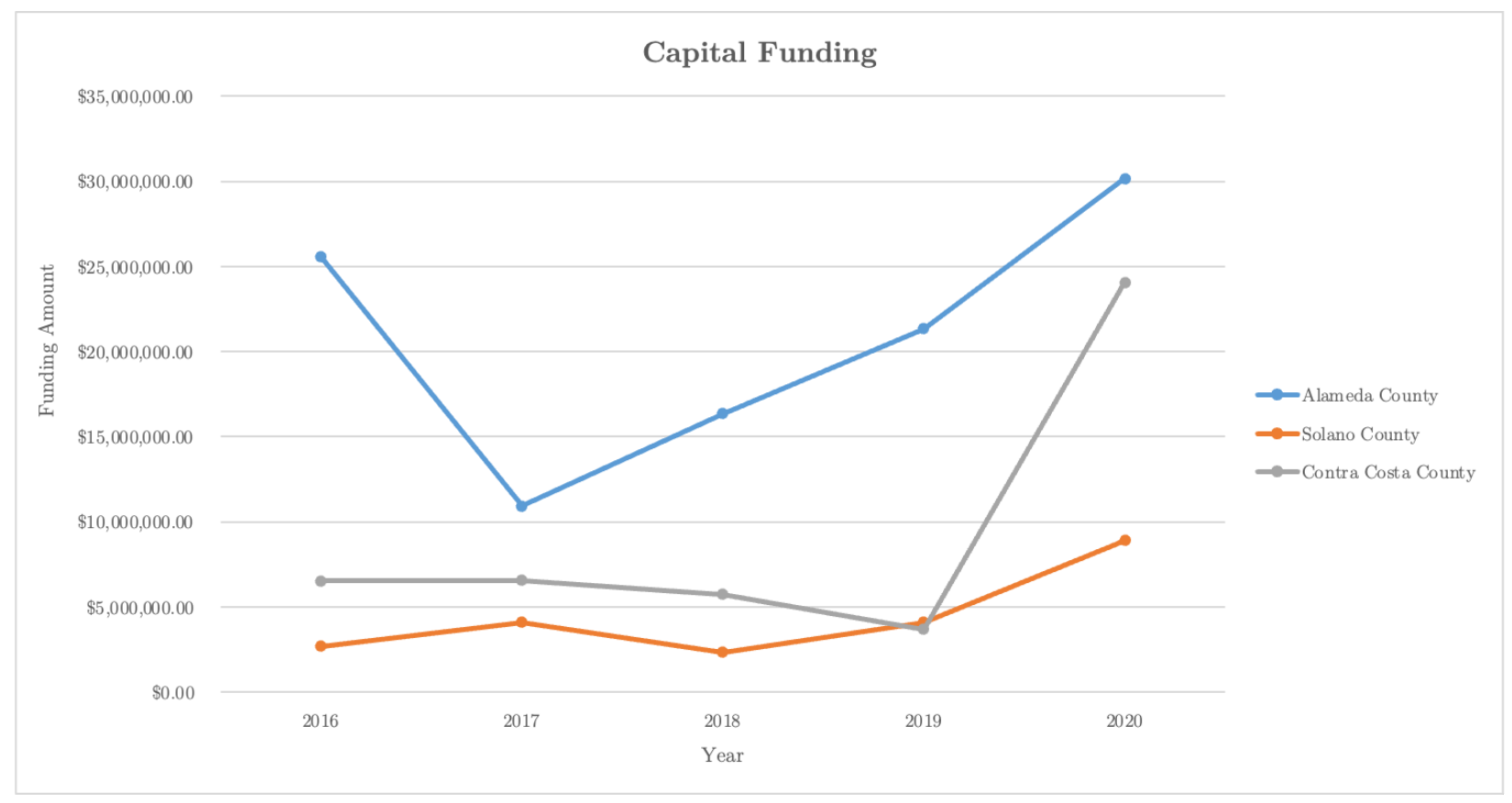

\section{i. Analysis of Capital Funding Data}

When comparing the capital funding data for all three SBDC programs at once (See Figure 11), it is clear that the Alameda County SBDC program out-performs the other programs and has been doing so for the past few years. However, although the centers do perform at varying levels, the trends can still be compared. The trend lines for Solano County and Contra Costa County SBDC programs show that the overall SBDC program performance for the Northern California region was in an overall decline between 2017 and 2019. However, starting from the end of 2018 (marking the start of the integration with Ohlone College's Tri-Cities Career Center), the Alameda County SBDC continued to grow its capital funding, reaching a highest-point at the end of the 2020 fiscal year. 


\section{FIGURE 12: Counseling Data - Alameda, Solano and Contra Costa SBDC}

*Data values for funding coming from sources unrelated to SBDC have been ommitted in the final calculations.

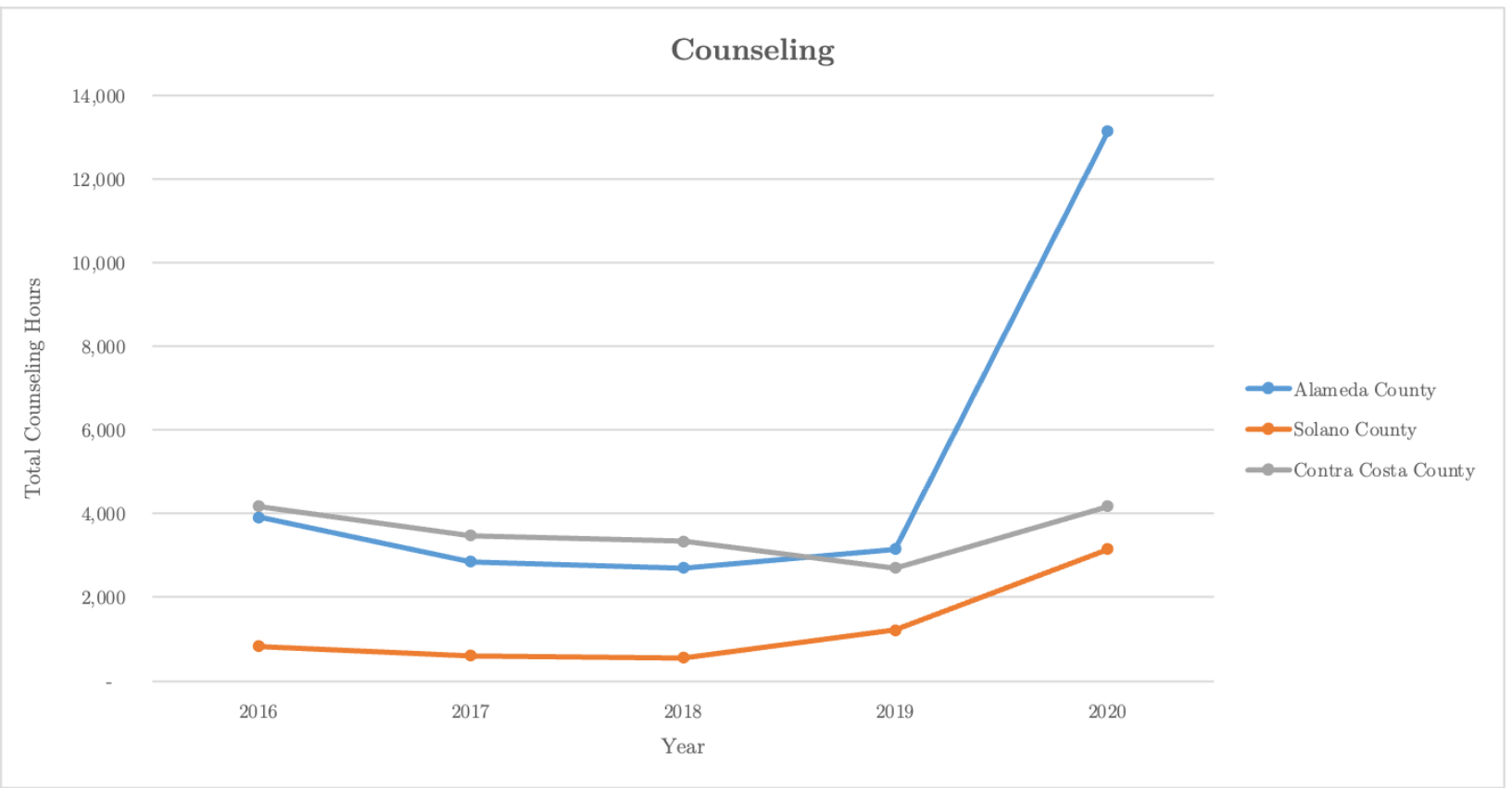

\section{ii. Analysis of Counseling Data}

A comparison of the counseling data for all three SBDC programs (See Figure 12) shows that the Alameda County SBDC struggled to perform well between 2016 and the end of 2018, often in a decline while other centers were at an incline. In 2019 (the start of the program's integration into Ohlone College), however, the Alameda County SBDC program showed a small growth in performance, which was then followed by a monumental increase in performance in 2020. This growth matches the overall trend in the region, as both Solano and Contra Costa County SBDC programs also show an increase in counseling hours during that period. The impact of the integration with Ohlone, however, is what enabled the Alameda County SBDC to increase counseling hours by about 10,000 while the other centers only increased by about 2,000 hours each. 


\section{FIGURE 13: Training Event Data - Alameda, Solano and Contra Costa SBDC}

*Data values for funding coming from sources unrelated to SBDC have been ommitted in the final calculations.

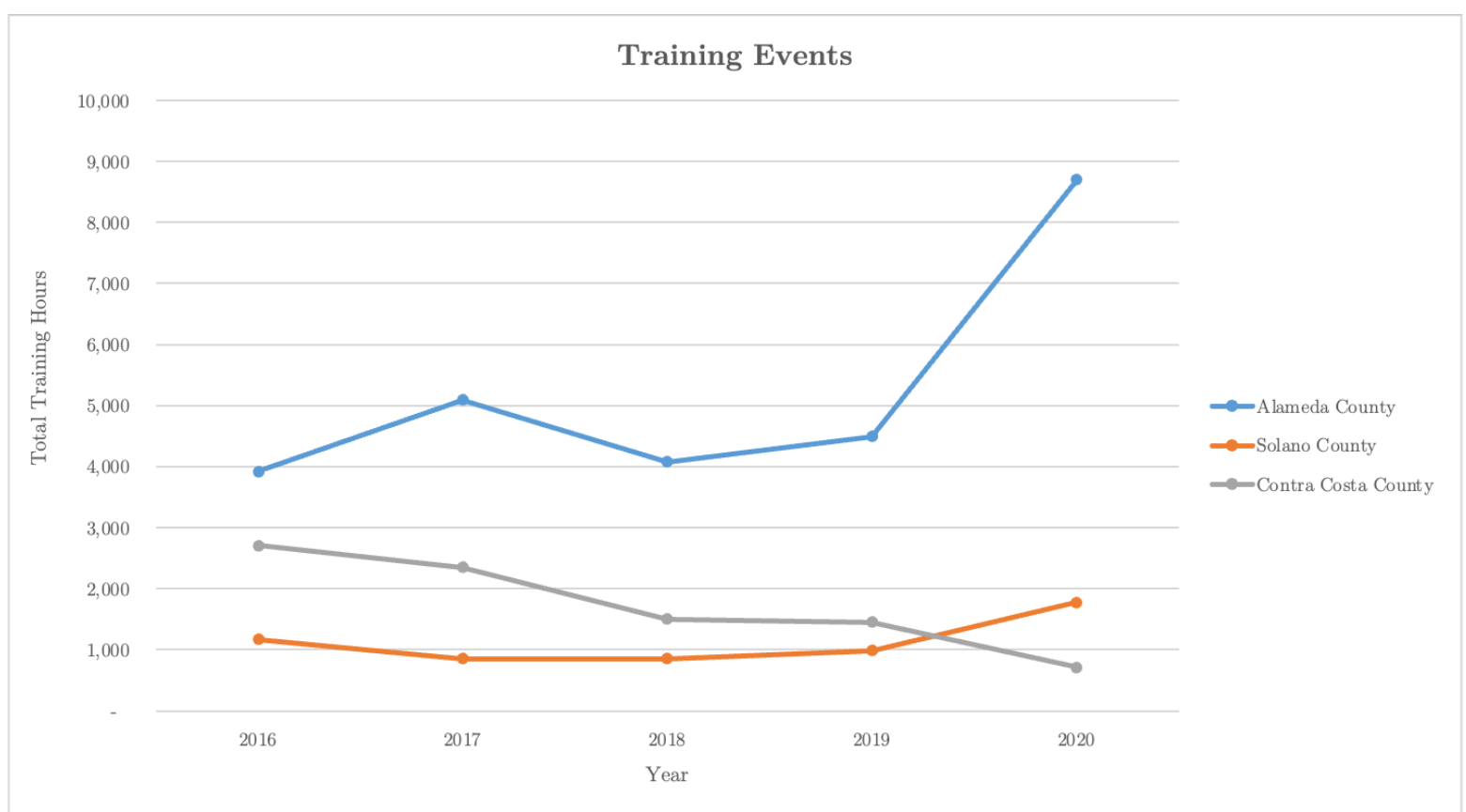

\section{iii. Analysis of Training Event Data}

Figure 13 compares all three SBDC programs in training event performance over a fiveyear period from 2016-2020. This comparison displays an overall decline in training event performance in the region, as the Solano County SBDC program fluctuates and the Contra Costa County SBDC program shows a consistent decline over the five-year period. The Alameda County SBDC program seems to match this regional trend, but only until the end of 2018. Right at the start of the 2019 fiscal year (the start of the integration into Ohlone College), the program starts to perform better. This small growth, similar to that in counseling, is followed by a very significant increase. While the Solano County SBDC program increased by about 1,000 training event hours, the Alameda County SBDC program increased its performance by about 5,000 training event hours. 


\section{CONCLUSION}

Based on the findings of this research, it is clear that the integration of a Small Business Development Center (SBDC) program into a college or university career services center has a positive impact on the performance of the SBDC program. The Tri-Cities Career Center at the Ohlone Community College District has showcased a set of interventions that have been used to better integrate its SBDC program in Alameda County.

A consideration that must be made when reviewing this research is the fact that all SBDC programs in the region were affected by the COVID-19 pandemic in the 2020 fiscal year. This pandemic may have led to many issues for local small businesses but was met with various sources of funding and supportive resources coming from the federal, state and county level. Despite this context, however, the Alameda County SBDC program has still outperformed other centers as a result of its integration with the Ohlone College Tri-Cities Career Center.

Another important consideration to be made for this research is the factor of longevity. While other programs in the region have had many years to adjust and integrate with their host, the Alameda County SBDC program has only been with Ohlone College for a mere two years. The program has yet to continue its integration with the Tri-Cities Career Center and the institution as a whole over the next few years, and potentially demonstrate even larger margins of growth.

This research has determined that the integration of an SBDC program into a college or university career services center has a positive impact on the performance and productivity of the SBDC program. However, based on the two-tiered approach in the methodology used in this research, the Ohlone College Tri-Cities Career Center has produced a new model for hosting an SDBC program. Through the quasi-experimental and non-experimental portions of this research, 
it was discerned that not only has the Alameda County SBDC program performed better now (under Ohlone College as its host) than it has in previous years while being hosted by other organizations/agencies, but it has also out-performed other SBDC programs in the Northern California region. This research suggests that college and university career services centers across the nation should be considered as not only feasible, but ideal hosts for the SBDC program, as they assist in increasing the economic impact and customer satisfaction of the program. 


\section{SOURCES CONSULTED}

A Brief History of America's SBDC Network. (n.d.). America's SBDC. Retrieved October 4, 2020, from https://americassbdc.org/about-us/a-brief-history/

About Us-Career Center. (2018, April 30). Ohlone College, A World of Cultures United in Learning - Ohlone College, Fremont and Newark, California.

https://www.ohlone.edu/careercenter/about-us

Alameda County Workforce Development Board. (2019). Biotech \& advanced manufacturing rapid reemployment (BAMMR). https://www.acwdb.org/acwdbassets/docs/RFI\%202019_Final.pdf

Bean, J. (2001). Big Government and Affirmative Action: The Scandalous History of the Small Business Administration. University Press of Kentucky. http://ebookcentral.proquest.com/lib/sjsu/detail.action?docID=1915387

California Community Colleges Chancellor's Office. (n.d.). Key facts. Retrieved November 30, 2020, from https://www.cccco.edu/About-Us/Key-Facts

California Community Colleges Chancellor's Office. (n.d.). Strong Workforce Program. |Retrieved November 30, 2020, from https://www.cccco.edu/About-Us/ChancellorsOffice/Divisions/Workforce-and-Economic-Development/Strong-Workforce-Program Career Center. (2018, February 14). Ohlone College, A World of Cultures United in Learning Ohlone College, Fremont and Newark, California. https://www.ohlone.edu/careercenter

Centaur Associates, Inc. (1983). An evaluation of the economic impact of the Small Business Development Center program. Washington, DC: Small Business Administration.

Chrisman, J.J., Hoy, F., \& Robinson Jr., R. B., \& Nelson, R. R., (1985). The impact of SBDC consulting activities. Journal of Small Business Management, 23(3), 1. 
Chrisman, J. J., Hoy, F., Robinson Jr., R. B., \& Nelson, R. R. (1987). Evaluating the Impact of SBDC Consulting: A Reply to Elstrott. Journal of Small Business Management - Taylor \& Francis Ltd., 25(1), 72-75.

Cook Center for Entrepreneurship. (n.d.). Ivy Tech Community College of Indiana. Retrieved

October 3, 2020, from https://www.ivytech.edu/bloomington/entrepreneurship/index.html

Elstrott, J. B. (1987). Procedure for Improving the Evaluation of SBDC Consulting Activities. Journal of Small Business Management - Taylor \& Francis Ltd., 25(1), 67-71.

Employer and Entrepreneurship Advisor Job Description | Ohlone College. (2019). Ohlone College, A World of Cultures United in Learning - Ohlone College, Fremont and Newark, California.

https://www.ohlone.edu/sites/default/files/groups/Board_of_Trustees/2019/081419/12battachmentaemployerentrepreneurshipadvisor0819.pdf

Entrepreneurship Services-Ohlone College Tri-Cities Career Center. (2019, July 6). Ohlone College, A World of Cultures United in Learning - Ohlone College, Fremont and Newark, California. https://www.ohlone.edu/careercenter/entrepreneurs Federal Student Aid - Job Location and Development. (n.d.). IFAP: Federal Work-Study Program. Retrieved November 30, 2020, from https://ifap.ed.gov/federal-student-aidhandbook/07-07-1998-federal-work-study-program-job-location-and-development Hart, C. (2018). Doing a Literature Review: Releasing the Research Imagination (2nd ed.). SAGE Study Skills. History of Ohlone College. (2018, January 9). Ohlone College, A World of Cultures United in Learning - Ohlone College, Fremont and Newark, California. https://www.ohlone.edu/ohlonehistory 
Hodes, R. (1981). The Florida Small Business Development Center Program (Oversight Report). Krentzman, H. C., \& Samaras, J. N. (1960). Can Small Businesses Use Consultants? Harvard Business Review.

Lang, J. R., \& Golden, P. A. (1989, April). Evaluating the Efficiency of SBDCs with Data Envelopment Analysis: A Longitudinal Approach - ProQuest. http://www.proquest.com/docview/220997453?OpenUrlRefId=info:xri/sid:primo\&accou ntid $=10361$

Lee, K. S. (1998, September 18). Performance Measurement in the SBDC Program. Small Business Administration (SBA). https://www.sba.gov/sites/default/files/oig/[c]\%20Inspection\%20Report\%2098-09$01 \% 20-$ \%20Performance\%20Measurement\%20in\%20the\%20SBDC\%20Program\%209.18.98.pd $\mathrm{f}$

Major Impact Study of SBA Management Counseling and Training Programs. (1980). Rockville Consulting Group Inc.

Newell, D. (2018). Leveraging the Workforce Innovation \& Opportunity Act (WIOA) to Help Finance College \& University Career Centers [Master's Projects, San Jose State University]. https://scholarworks.sjsu.edu/etd_projects/584

OBDC Small Business Finance Wins Bid to Host Local SBDC. (2016). Politics \& Government Business, 40, 40. Gale General OneFile.

Ohlone Career Center. (2018, April). Alameda County Workforce Development Board. http://tricitiesonestop.com/wiaorientation2.php 
Olson, S. (2006). Ivy Tech to host SBDC: State hopes partnership will end instability, help local center shine as consultant. Indianapolis Business Journal, 27(29), 35A-. Gale OneFile: Entrepreneurship.

Our Host: Ohlone College | Alameda SBDC. (n.d.). Alameda County Small Business Development Center (ACSBDC). Retrieved October 4, 2020, from https://www.acsbdc.org/about-us/our-host-ohlone-college-alameda-sbdc

Quick Facts. (2018, January 9). Ohlone College, A World of Cultures United in Learning Ohlone College, Fremont and Newark, California. https://www.ohlone.edu/quick-facts Robinson Jr., R. B. (1980). An Empirical Investigation of the Impact of SBDC-Strategic Planning Consultation Upon the Short-Term Effectiveness of Small Businesses in Georgia [Unpublished]. University of Georgia.

S.918 - 96th Congress (1979-1980): Small Business Development Center Act of 1979, (1980). https://www.congress.gov/bill/96th-congress/senate-bill/918

Santa Fe Community College. (n.d.). SFCC Employer Services. Retrieved October 3, 2020, from https:/www.sfcc.edu/employer-services/

Thompson, R. G., Dharmapala, P. S., Gatewood, E. J., Macy, S., \& Thrall, R. M. (1996). DEA/Assurance Region SBDC Efficiency and Unique Projections. Operations Research - INFORMS, 44(4), 533-542. JSTOR.

University of Scranton Small Business Development Center (SBDC).(n.d.) | Helping NEPA \& Northern Tier small businesses start, grow \& prosper. University of Scranton Small Business Development Center ( SBDC ). Retrieved October 4, 2020, from https://www.scrantonsbdc.com/ 
Unnamed Press Release | Small Business Administration. (1976). Small Business Administration Press Releases.

U.S. Small Business Administration. (1979). An in depth study of eight small business development centers (pilot study). U.S. Small Business Administration.

U.S. Small Business Administration. (n.d.). History of SBA. Retrieved October 19, 2020, from https://www.sba.gov/about-sba/organization

Weaver, M. K. (1981). National Small Business Institute Evaluation. U.S. Small Business Administration.

Who We Are | Alameda SBDC. (n.d.). Alameda County Small Business Development Center. Retrieved October 4, 2020, from https://www.acsbdc.org/about-us/who-we-are-alamedasbdc

Who We Are | Northern California SBDC Network. (n.d.). Northern California SBDC Network. Retrieved October 4, 2020, from https://www.norcalsbdc.org/about-us/who-we-arenorthern-california-sbdc-network

Workforce Development Board | Alameda County. (n.d.). Alameda County Workforce Development Board. Retrieved November 30, 2020, from https://www.acwdb.org/index.page? 